\title{
Oligodendrocyte/Type-2 Astrocyte Progenitor Cells and Glial-Restricted Precursor Cells Generate Different Tumor Phenotypes in Response to the Identical Oncogenes
}

\author{
Jun Wang, ${ }^{1}$ Jared Bushman, ${ }^{2}$ Xi Wang, ${ }^{3}$ Margot Mayer-Proschel, ${ }^{1}$ Mahlon Johnson, ${ }^{4}$ and Mark Noble ${ }^{1}$ \\ ${ }^{1}$ Department of Biomedical Genetics and University of Rochester Stem Cell and Regenerative Medicine Institute, University of Rochester School of Medicine \\ and Dentistry, Rochester, New York 14642, ${ }^{2}$ New Jersey Center for Biomaterials, Piscataway, New Jersey 08854, ${ }^{3}$ Cleveland Clinic, Cleveland, Ohio, 44109, \\ ${ }^{4}$ Department of Pathology and Laboratory Medicine, University of Rochester School of Medicine and Dentistry, Rochester, New York 14642
}

\begin{abstract}
Despite the great interest in identifying the cell-of-origin for different cancers, little knowledge exists regarding the extent to which the specific origin of a tumor contributes to its properties. To directly examine this question, we expressed identical oncogenes in two types of glial progenitor cells, glial-restricted precursor (GRP) cells and oligodendrocyte/type-2 astrocyte progenitor cells (0-2A/OPCs), and in astrocytes of the mouse CNS (either directly purified or generated from GRP cells). In vitro, expression of identical oncogenes in these cells generated populations differing in expression of antigens thought to identify tumor initiating cells, generation of 3D aggregates when grown as adherent cultures, and sensitivity to the chemotherapeutic agent BCNU. In vivo, cells differed in their ability to form tumors, in malignancy and even in the type of host-derived cells infiltrating the tumor mass. Moreover, identical genetic modification of these different cells yielded benign infiltrative astrocytomas, malignant astrocytomas, or tumors with characteristics seen in oligodendrogliomas and small-cell astrocytomas, indicating a contribution of cell-of-origin to the characteristic properties expressed by these different tumors. Our studies also revealed unexpected relationships between the cell-of-origin, differentiation, and the order of oncogene acquisition at different developmental stages in enabling neoplastic growth. These studies thus provide multiple novel demonstrations of the importance of the cell-of-origin in respect to the properties of transformed cells derived from them. In addition, the approaches used enable analysis of the role of cell-of-origin in tumor biology in ways that are not accessible by other more widely used approaches.
\end{abstract}

\section{Introduction}

Determining whether particular CNS cell types give rise to particular gliomas is of great interest both in regards to identifying potential tumor origins and in determining whether the specific cell-of-origin is relevant to tumor phenotype. Studies in transgenic mice indicate gliomas can be generated from multiple cell types, including neuroepithelial stem cells (NSCs), oligodendrocyte lineage cells, astrocytes, and potentially even neurons (Alcantara Llaguno et al., 2009; Lindberg et al., 2009; Jacques et al., 2010; Liu et al., 2011; Friedmann-Morvinski et al., 2012; Ghazi et al., 2012; Swartling et al., 2012). Some of these studies further suggest an important influence of the cell-of-origin on tumor

Received Feb. 5, 2013; revised Aug. 24, 2013; accepted Sept. 6, 2013.

Author contributions: J.W. and M.N. designed research; J.W., J.B., and X.W. performed research; J.W., M.M.-P., M.J., and M.N. analyzed data; J.W. and M.N. wrote the paper.

This research was supported by the National Institutes of Health (R01CA131385), the Department of Defense (W81XWH-07-1-0601), the New York State Department of Health C026437, and the Carlson Stem Cell Fund. We are grateful to the multiple colleagues who have provided insightful comments on these studies, and in particular to Craig Jordan, Chris Pröschel, Hartmut Land, and Helene McMurray.

The authors declare no competing financial interests.

Correspondence should be addressed to Mark Noble, Department of Biomedical Genetics and University of Rochester Stem Cell and Regenerative Medicine Institute, University of Rochester School of Medicine and Dentistry, 601 Elmwood Avenue, Box 633, Rochester, New York 14642. E-mail: mark_noble@urmc.rochester.edu.

DOI:10.1523/JNEUROSCI.0546-13.2013

Copyright $\odot 2013$ the authors $\quad 0270-6474 / 13 / 3316805-13 \$ 15.00 / 0$ phenotype, but the degree of such influence remains poorly understood.

Some of the challenges in determining whether the cell-oforigin contributes to tumor phenotype are illustrated by the specific generation of oligodendrogliomas in TP53-/- mice expressing the constitutively active v-erbB mutant of the epidermal growth factor receptor (EGFR) under control of the $S 100 \beta$ promoter (Weiss et al., 2003; Persson et al., 2010). This outcome is surprising as $S 100 \beta$ is expressed in multiple cell types, including both oligodendrocyte and astrocyte lineage cells (Liu et al., 2002, 2004; Vives et al., 2003; Steiner et al., 2007).

Why does this combination of genetic changes produce only oligodendrogliomas? Possibly, CNS cells expressing these oncogenes generate oligodendrogliomas regardless of the cell-oforigin. Alternatively, does this oncogene combination only transform specific cells that generate oligodendrogliomas? If so, what are these cells?

In the CNS, multiple precursor cells, astrocytes, and NSCs all offer potential targets for malignant transformation. Among these, glial-restricted precursor (GRP) cells and oligodendrocyte/ type-2 astrocyte progenitor cells (also known as oligodendrocyte precursor cells, O-2A/OPCs) represent two well studied distinct glial precursor subtypes useful for addressing the above questions. Although both GRP cells and O-2A/OPCs are restricted to glial development and can generate oligodendrocytes (Raff et al., 
1983; Groves et al., 1993; Rao et al., 1998; Herrera et al., 2001), they differ in mitogen and substrate requirements, differentiation potential, the timing of their developmental appearance, and the number of astrocyte subtypes they can generate. GRP cells have been studied in the context of development, gestational iron deficiency, sensitivity to chemotherapeutic agents, as promoters of CNS protection and regeneration, and in development of astrocyte transplantation therapies (Noble et al., 2004; Davies et al., 2011; Ketschek et al., 2012 and their references), but nothing is known about the consequences of GRP cell transformation.

As no known promoters enable targeting of oncogene expression distinctly and unambiguously to O-2A/OPCs versus GRP cells, we used an alternative strategy of introducing identical oncogenic changes directly in purified cells. We also took advantage of the ability of GRP cells to generate astrocytes to investigate effects of astrocytic differentiation on the response to oncogene expression. Our results demonstrate an unexpected breadth of cell-of-origin contributions to tumor phenotype, including effects on malignancy, type of tumor generated, type of host cells within the tumor mass, expression of putative markers of tumor initiating cells, and cellular resistance to chemotherapy.

\section{Materials and Methods}

Construction of retroviral vectors. The retroviral vectors pBabe-Puromycin, pBabe-Hygromycin, pBabe-Zeocin, and pBabe-DNp53-Puromycin expressing a dominant-negative p53 (DNp53), due to a point mutation of p $53^{\mathrm{R} 175 \mathrm{H}}$ affecting the DNA binding ability, were kindly provided by the lab of Dr. Hartmut Land. The retroviral vector pBabe-PDGFR $\alpha$-Zeocin vector was constructed by inserting the fragment encoding PDGFR $\alpha$ into the pBabe-Zeocin vector. The retroviral vector $\mathrm{pBabe-luciferase-}$ Hygromycin vector was constructed by inserting the fragment encoding luciferase from firefly Photinus pyralis (pEGFPLuc from BD Biosciences) into the pBabe-Hygromycin vector. The correct clones were confirmed by sequencing. The retroviral vector pBabe-EGFRvIII-Zeocin expressing constitutively active EGFR was kindly provided by Dr. Oliver Bogler at Baylor Medical Center.

Culture of GRP cells, O-2A progenitor cells, and astrocytes. GRP cells were isolated from embryonic day 12.5 spinal cord, O-2A progenitor cells were isolated from postnatal day 6 (P6) corpus callosum, and astrocytes were isolated from P1 cortex of C57BL/6 mice using standard procedures (Noble et al., 1984; Groves et al., 1993; Ibarrola et al., 1996; Rao et al., 1998; Herrera et al., 2001; Gregori et al., 2002; Power et al., 2002). Tissues were processed to single-cell suspensions, and cells were purified using surface cell type-specific markers and cultured in conditions that maintain their respective differentiation potential in vitro. GRP cells were purified by fluorescence-activated cell sorting (FACS) or magnetic cell sorting (MACS) for A2B5-positive cells and were then cultured in the defined medium-DMEM/F12 supplemented with $1 \mu \mathrm{g} / \mathrm{ml}$ bovine pancreas insulin (Sigma), $100 \mu \mathrm{g} / \mathrm{ml}$ human transferrin (Sigma), $2 \mathrm{~mm}$ glutamine, $25 \mu \mathrm{g} / \mathrm{ml}$ gentamicin, $0.0286 \%$ (v/v) bovine serum albumin pathocyte (ICN Biochemicals), $0.2 \mu \mathrm{M}$ progesterone (Sigma), $0.10 \mu \mathrm{M}$ putrescine (Sigma)-supplemented with basic fibroblast growth factor (bFGF; $10 \mathrm{ng} / \mathrm{ml}$; PEPRO Technologies) in flasks coated with $20 \mu \mathrm{g} / \mathrm{ml}$ fibronectin (Millipore Bioscience Research Reagents) and $5 \mu \mathrm{g} / \mathrm{ml}$ laminin (Invitrogen). O-2A progenitor cells were purified by MACS for A2B5-positive cells and were cultured in the defined medium supplemented with $10 \mathrm{ng} / \mathrm{ml}$ bFGF (PEPRO Technologies), and $10 \mathrm{ng} / \mathrm{ml}$ PDGF-AA(PEPRO Technologies) in flasks coated with $13.3 \mu \mathrm{g} / \mathrm{ml}$ polyL-lysine (PLL; Sigma). Astrocytes were cultured in the defined medium containing $10 \%$ fetal bovine serum (FBS) in flasks coated with 13.3 $\mu \mathrm{g} / \mathrm{ml}$ PLL. The dose curves of GRP cells, O-2A progenitors, and astrocytes to puromycin, Zeocin, and hygromycin were tested in 6-well plates at the density of $3 \times 10^{4}$ cells/well.

Cell line generation by sequential retroviral infection. Cell populations for study in vitro and in vivo were generated from pools of heterogeneous transduced cell O-2A/OPCs, GRP cells, and astrocytes with various integration sites and copy numbers. All cell populations were generated at least twice in independent experiments. Virus packaging cell line GP2293 cells $\left(3-5 \times 10^{6}\right)$ were plated on $10 \mathrm{~cm}$ dishes the day before transfection. Retroviral vector pBabe-DNp53-Puromycin and envelope vector pVSV-G were cotransfected into GP2-293 cells by Fugene6 (Roche). Retrovirus supernatant was harvested $48 \mathrm{~h}$ after transfection. The growth medium containing the retrovirus carrying DNp53 was incubated with the target GRP cells, O-2A progenitor cells, and astrocytes at $30^{\circ} \mathrm{C}$ overnight. Following a recovery period of $48 \mathrm{~h}$, the infected cells were selected for resistance to puromycin to generate $\mathrm{DNp} 53$-transduced GRP cells, O-2A progenitor cells, and astrocytes. The following concentrations of puromycin were used: $200 \mathrm{ng} / \mathrm{ml}$ for GRP cells and O-2A progenitor cells and $2 \mu \mathrm{g} / \mathrm{ml}$ puromycin for astrocytes.

GRP cells, O-2A progenitor cells, and astrocytes expressing DNp53 were transduced to express PDGFR $\alpha$ by infection with retroviral vector pBabe-PDGFR $\alpha$-Zeocin and selected for resistance to Zeocin to generate $\left(\mathrm{G}^{53 P}\right)$ cells, O-2A progenitor cells-DNp53-PDGFR $\alpha\left(\mathrm{O}^{53 P}\right)$ cells, and astrocyte-DNp53-PDGFR $\alpha\left(\mathrm{A}^{53 P}\right)$ cells. Similarly, DNp53-transduced GRP cells, O-2A progenitor cells, and astrocytes were transduced with EGFRvIII by retroviral vector pBabe-EGFRvIII-Zeocin and selected for resistance to Zeocin to generate GRP cells-DNp53-EGFRvIII $\left(\mathrm{G}^{53 E}\right)$, $\mathrm{O}-2 \mathrm{~A}$ progenitor cells-DNp53-EGFRvIII $\left(\mathrm{O}^{53 E}\right)$ cells, and astrocytesDNp53-EGFRvIII $\left(\mathrm{A}^{53 E}\right)$ cells. The following concentrations of Zeocin were used: $20 \mu \mathrm{g} / \mathrm{ml}$ for GRP cells and O-2A progenitor cells, $2 \mathrm{mg} / \mathrm{ml}$ for astrocytes. Finally, all types of DNp53/EGFRvIII or DNp53/PDGFR $\alpha$ transduced cells were transduced with luciferase by retroviral vector pBabe-Luciferase-Hygromycin and selected for resistance to hygromycin. The following concentrations of hygromycin were used: 100 $\mu \mathrm{g} / \mathrm{ml}$ for GRP cells and O-2A progenitor cells, $50 \mu \mathrm{g} / \mathrm{ml}$ hygromycin for astrocytes.

To generate GRP cells-EGFRvIII-astrocytes-DNp53 $\left(\mathrm{G}^{E} \mathrm{~A}^{53}\right)$ and GRP cells-DNp53-astrocytes-EGFRvIII $\left(\mathrm{G}^{53} \mathrm{~A}^{\mathrm{E}}\right)$ cells, the GRP cells and O-2A progenitor cells bearing single EGFRvIII or DNp53 were treated with astrocyte differentiation medium containing $10 \%$ FBS for $4 \mathrm{~d}$. The astrocytes derived from $\mathrm{O}-2 \mathrm{~A}$ progenitor cells-DNp53 stopped dividing. The astrocytes derived from GRP cells-EGFRvIII were transduced with the oncogene DNp53 to generate $G^{E} A^{53}$ cells. Similarly the astrocytes derived from GRP cells-DNp53 were transduced with the oncogene EGFRvIII to generate $\mathrm{G}^{53} \mathrm{~A}^{E}$ cells.

The expression of EGFRvIII and PDGFR $\alpha$ was analyzed by Western blot analysis using anti-EGFR antibody (1:1000, sc-3; Santa Cruz Biotechnology) and anti-PDGFR $\alpha$ antibody (1:1000, sc-338; Santa Cruz Biotechnology); the expression of DNp53 was confirmed by immunoprecipitating with anti-total p53 antibody ( $1 \mu \mathrm{g}$, sc-99; Santa Cruz Biotechnology) and immunoblotting with anti-DNp53 antibody (1:1000, sc-6243; Santa Cruz Biotechnology). The expressions of luciferase were tested by luciferase assay with microplate reader (Promega).

FACS analysis. Each population of transduced cells was dissociated with HBSS/EDTA and collagenase (Worthington Biochemicals) to form single-cell suspensions. Cells were stained with FACS buffer containing the primary antibody against Prominin1/CD133 (MB9-3G8; Miltenyi Biotec) for $30 \mathrm{~min}$ on ice, followed by a secondary anti-rat IgG antibodyconjugated FITC for 20 min on ice. Similarly each type of transduced cell was stained with FITC mouse anti-SSEA-1 (BD PharMingen) for $30 \mathrm{~min}$ on ice. The controls were cells only stained with secondary antibodyconjugated FITC. Propidium iodide or DAPI were added as viability exclusion dyes. FACS analysis was used to determine the percentage of cells positive for Prominin1 (CD133) or LeX (CD15). The gates were set based on the controls being $0.05 \% \mathrm{CD} 33^{+}$or $\mathrm{LeX}^{+}$.

Spheroid-forming assay. The cells were plated at 10,000 cells/well on 12 -well plates coated with anti-adhesive polyHEMA $\left(1.6 \mathrm{mg} / \mathrm{cm}^{2}\right)$, uncoated plates, or plates coated with substrate for studying comparable primary cells (fibronectin and laminin for GRP-derived cells; PLL for $\mathrm{O}-2 \mathrm{~A}$ progenitors/astrocytes-derived cells). The spheres were observed after $7 \mathrm{~d}$ of in vitro growth.

Limiting dilution analysis. Cells were plated in 96-well plates directly or plates coated with polyHEMA or serial dilution of substrates used for studying their primary counterparts. Cell dilutions ranged from 10 cells/ well to 2000 cells/well in $100 \mu$ l aliquots. After $7 \mathrm{~d}$, the fraction of wells 


\begin{tabular}{|c|c|}
\hline Cell type & Abbreviation \\
\hline O-2A-DNp53-EGFRvIII & $0^{53 E}$ \\
\hline O-2A-DNp53-PDGFR a & $\mathrm{O}^{53 P}$ \\
\hline GRP-DNp53-EGFRvIII & $G^{53 E}$ \\
\hline GRP-DNp53-PDGFR $a$ & $\mathrm{G}^{53 P}$ \\
\hline GRP-DNp53-astrocyte-EGFRvIII & $G^{53} A^{E}$ \\
\hline GRP-EGFRvIII-astrocyte-DNp53 & $G^{E} A^{53}$ \\
\hline astrocyte-DNp53-EGFRvIII & $A^{53 E}$ \\
\hline astrocyte-DNp53-PDGFR a & $A^{53 P}$ \\
\hline
\end{tabular}

C

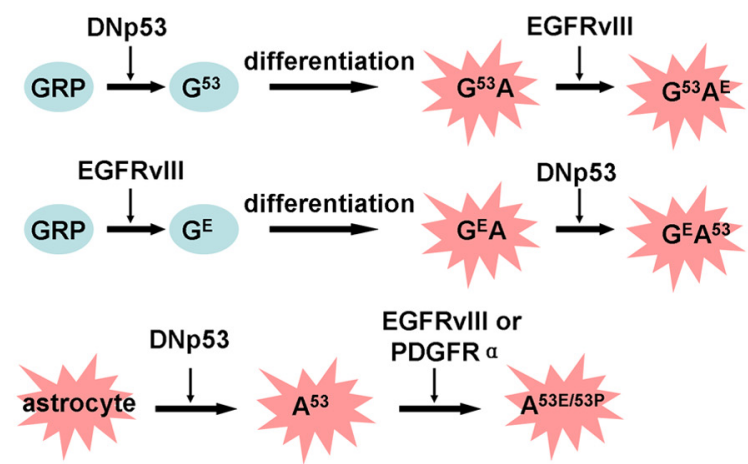

B

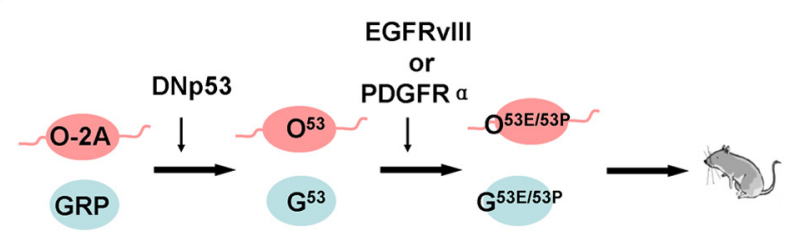

D

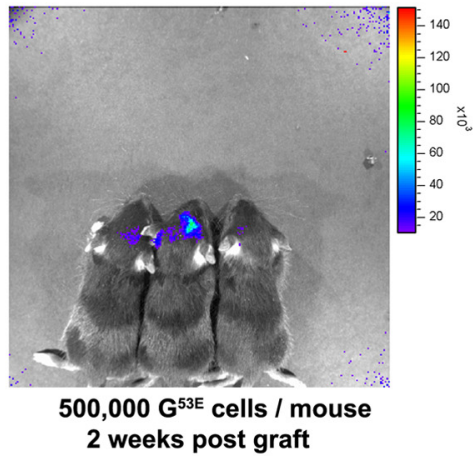

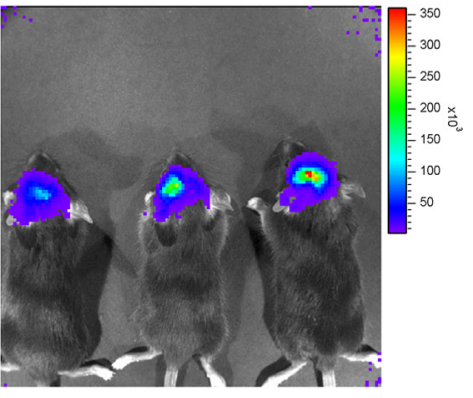

3 weeks post graft

Figure 1. Schematic summary of the isograft mouse model. $A, 53$, DNp53; E, EGFRvIll; P, PDGFR $\alpha ; 0,0-2$ A progenitor cells; $G, G R P$ cells; and A, type-1-astrocytes. $B$, Cell lines were generated from $0-2 \mathrm{~A} / \mathrm{OPCS}$ or GRP cells by retroviral-mediated gene transfer with dominant-negative TP53 (DNp53) combined with EGFRvill or PDGFR $\alpha$. C, Cell lines were generated by first introducing DNp53 or EGFRvIll in GRP cells, inducing astrocyte differentiation and then introducing the complementary oncogene. DNp53 and EGFRvlll were also directly introduced into purified cortical astrocytes. D, Cells were also transduced to express firefly luciferase, allowing visualization of their growth in vivo. The tumor formation visualized by bioluminescence scanning in vivo was further confirmed by $H \& E$ staining.

containing neurospheres or 3D foci for each cell-plating density was calculated.

Intracranial cell transplantation into C57BL/6 mice. Cells were suspended in $0.3-2 \mu \mathrm{l}$ of PBS in aliquots of 500,000 cells or 25,000 cells. These aliquots were intracranially transplanted into C57BL/6 male or female neonatal mouse striatum of the left hemisphere, following anesthesia by hypothermia. The injection coordinates were $1 \mathrm{~mm}$ to the left of the midline, $0.5 \mathrm{~mm}$ anterior to coronal suture, and $1.5 \mathrm{~mm}$ deep to P3-P4 mice, or $2 \mathrm{~mm}$ deep to P7 mice.

Bioluminescence scanning. At 24 h, 2 weeks, 3 weeks, 4 weeks, and 5 weeks post-transplantation, luciferase substrate D-luciferin firefly potassium salt solution (Xenogen) was injected intraperitoneally into mice following administration of anesthesia, and after $10 \mathrm{~min}$ the mice were imaged by IVIS 100 imaging system (Xenogen) to monitor the growth of transplanted cells based on the activity of expressed luciferase.

Mouse brain fixation and histopathology. The mice with tumors detected by bioluminescence scanning were killed after 2 weeks, 3 weeks, 4 weeks, or 5 weeks and the mice without luminescence-detected tumors were killed in weeks $4-6$ by cardiac perfusion-fixation with heparin followed by $4 \%$ paraformaldehyde under anesthesia. The whole brains were isolated, postfixed (overnight at $4^{\circ} \mathrm{C}$ ), cryoprotected in $30 \%$ sucrose (overnight at $4^{\circ} \mathrm{C}$ ), embedded into optimal cutting temperature compound, and cut coronally into $14 \mu \mathrm{m}$ as cryostat sections, and stored at $4^{\circ} \mathrm{C}$ in a cryoprotectant solution. Free-floating sections were mounted on HistoBond microscope slides. Hematoxylin and eosin (H\&E) staining, or immunofluorescence analysis, was performed on these frozen sections.

Immunofluorescent staining of brain tissues. The free-floating sections were rinsed in Tris-buffered saline (TBS) several times and incubated in TBS with $0.1 \%$ Triton X-100 and 3\% goat serum (TBS-plus) for $30 \mathrm{~min}$. Sections were then incubated with antibody against p53 (sc-6243; Santa Cruz Biotechnology), EGFR (sc-3; Santa Cruz Biotechnology), Ki67 (BD Pharmingen), LeX (BD Bioscience), Olig2 (Millipore Bioscience Research Reagents), CC1 (Calbiochem), NeuN (Millipore Bioscience Research Reagents), or $\beta$-tubulin III (Sigma) in TBS-plus for $48 \mathrm{~h}$ at $4^{\circ} \mathrm{C}$. Sections were rinsed several times in TBS and incubated for $1 \mathrm{~h}$ with secondary antibodies (Molecular Probes). After several washes in TBS,
Table 1. Summary of the isograft results of different glial cell types

\begin{tabular}{llll}
\hline Cell type & $\begin{array}{l}\text { Number of cells per } \\
\text { graft (number of mice) }\end{array}$ & $\begin{array}{l}\text { Tumor } \\
\text { incidence }\end{array}$ & $\begin{array}{l}\text { Weeks post } \\
\text { graft }\end{array}$ \\
\hline $0^{53 E}$ & $500,000(3)$ & $3 / 3$ & 2 \\
$0^{53 E}$ & $25,000(9)$ & $9 / 9$ & 4 \\
$0^{53 P}$ & $500,000(6)$ & $0 / 6$ & $4-6$ \\
$G^{53 E}$ & $500,000(3)$ & $3 / 3$ & 2 \\
$G^{53 E}$ & $25,000(4)$ & $2 / 4$ & 4 \\
$G^{53 P}$ & $500,000(8)$ & $0 / 8$ & $4-6$ \\
$G^{53} A^{E}$ & $25,000(4)$ & $0 / 4$ & $4-6$ \\
$G^{53} A^{E}$ & $500,000(1)$ & $0 / 1$ & $4-6$ \\
$G^{E} A^{53}$ & $25,000(4)$ & $4 / 4$ & $4-5$ \\
$A^{53 E}$ & $500,000(15)$ & $0 / 15$ & $4-6$ \\
$A^{53 E}$ & $137,500(4)$ & $0 / 4$ & 6 \\
$A^{53 P}$ & $500,000(6)$ & $0 / 6$ & $4-6$ \\
\hline
\end{tabular}

Luciferase-expressing cell lines were transplanted into mice at varying cell numbers and tumor development was followed by noninvasive imaging as indicated. All mice were examined histologically to confirm the results of noninvasive imaging studies.

sections were mounted on gelatin-coated glass slides using anti-fading mounting solution. The images were taken using a confocal laserscanning microscope (Leica TCS SP2).

Immunofluorescent staining of cells. Cells were seeded at 1000 cells/ coverslip and cultured in conditions that maintain their respective differentiation potential in vitro. After several days, cells were fixed in $2 \%$ paraformaldehyde for $10 \mathrm{~min}$ and stained with cell type-specific antibodies: the glial precursor cell marker A2B5, astrocyte marker glial fibrillary acid protein (GFAP), and DAPI. The images were observed using a Nikon Eclipse E400 microscope and Spot RT camera.

In vitro chemotherapy toxicity and viability assay. Control and transduced cells were plated in coated 96-well plates at a density of 1000 cells/well. After $24 \mathrm{~h}$, cells were treated for $\mathrm{BCNU}$ over a wide dose range for $1 \mathrm{~h}: 0.1 \mu \mathrm{M}-5 \mathrm{~mm}$ for $\mathrm{O}^{53 E}, \mathrm{G}^{E} \mathrm{~A}^{53}$, and $\mathrm{G}^{53} \mathrm{~A}^{E}$ cells, and $0.1-100 \mu \mathrm{M}$ for $\mathrm{O}-2 \mathrm{~A} / \mathrm{OPCs}$, GRP cells, and astrocytes as previously described (Dietrich et al., 2006; Han et al., 2008) and as determined by the half-life of BCNU 
in vivo. Cell survival was determined $48 \mathrm{~h}$ later by alamarBLUE combined with DAPI stain to analyze nuclear morphology. Quantification of cell viability through reading of UV absorption spectrums at $560 \mathrm{~nm}$ was performed on a microplate reader. Ki67 staining of $\mathrm{O}^{53 E}, \mathrm{G}^{E} \mathrm{~A}^{53}$, and $G^{53} A^{E}$ cells, plated at the same densities and cultured for $72 \mathrm{~h}$, was performed on substrate-coated coverslips using standard procedures (Noble et al., 1984; Groves et al., 1993; Ibarrola et al., 1996; Rao et al., 1998; Herrera et al., 2001; Gregori et al., 2002; Power et al., 2002).

\section{Results}

\section{Cells and oncogenes studied}

We first asked whether expression of oncogenic changes, shown previously to generate oligodendrogliomas in transgenic mice, caused two closely related glial progenitor cells both to generate oligodendrogliomas or whether the generation of oligodendrogliomas was specific to expression of these oncogenes in a specific cell type. The progenitor cells we studied were $O-2 A / O P C s$, the direct ancestors of myelin-forming oligodendrocytes, and GRP cells, the developmentally earliest known progenitor cell population restricted to the generation of glial cells of the CNS. Although similar in respect to labeling with the A2B5 antibody, in being responsive to FGF-2 as a mitogen and in being able to generate both oligodendrocytes and astrocytes, GRP cells and O-2A/

OPCs differ in their substrate requirements, timing of developmental appearance, ability to respond to plateletderived growth factor (PDGF) as a single mitogen, types of astrocytes they generate, and in other properties (Raff et al., 1983; Groves et al., 1993; Rao et al., 1998; Herrera et al., 2001; Noble et al., 2004; Davies et al., 2011; Ketschek et al., 2012). In particular respect to the studies we conducted, GRP cells are able to generate astrocytes antigenically similar to those that can be isolated from the cerebral cortex of young rats and mice, as well as being able to generate astrocytes with the distinctive (type-2) phenotype expressed by those generated from O-2A/OPCs (Raff et al., 1983; Rao et al., 1998; Noble et al., 2004). Extensive prior development of purification strategies for these progenitor cells, as well as for astrocytes isolated from cortices of young rodents, enable the generation of populations in which purity is $\geq 99.5 \%$, as demonstrated both by analysis of mass cultures and by clonal analysis properties (Noble et al., 1984; Groves et al., 1993; Ibarrola et al., 1996; Rao et al., 1998; Herrera et al., 2001; Gregori et al., 2002; Power et al., 2002). Moreover, due to the later appearance of $\mathrm{O}-2 \mathrm{~A} / \mathrm{OPCs}$ during development than GRP cells, it is possible to generate pure populations of GRP cells in which no O-2A/OPCs are present (Gregori et al., 2002).

To circumvent the lack of cell-specific promoters that allow selective targeting of oncogene expression to GRP cells or O-2A/ OPCs individually, we used retroviral-mediated gene transfer to express the dominant-negative $(\mathrm{p} 53175 \mathrm{H})$ mutant of the TP53 gene (DNp53) (Xia and Land, 2007) in purified cultures of O-2A/ OPCs and GRP cells. This was combined with retroviralmediated expression of either the truncated constitutively active
EGFRvIII variant of the EGFR (Huang et al., 1997) or the plateletderived growth factor receptor- $\alpha$ (PDGR $\alpha$; Fig. $1 A, B)$. Previous studies in transgenic mice have shown that expression of the constitutively active EGFR mutant v-erbB under control of the S100 $\beta$ promoter in a TP53-/- mouse selectively causes generation of oligodendrogliomas (Weiss et al., 2003; Persson et al., 2010). The oncogenic mutants that we used have biologically similar outcomes in terms of loss of p53 function and expression of constitutively active EGFR activity, but are more akin to the types of genetic changes that occur in human tumors. Mutations in TP53 are the most prevalent genetic alterations in gliomas (Stark et al., 2003), rather than homozygous loss as it occurs in TP53-/- mice. Amplified expression of EGFR and/or PDGR $\alpha$ also occurs in many gliomas (Parsons et al., 2008; Verhaak et al., 2010), and the EGFR is particularly prone to mutational changes (Martinho et al., 2009), with the EGFRvIII mutation occurring in $20-30 \%$ of all primary glioblastomas (Sugawa et al., 1990). This mutation causes constitutive tyrosine kinase activity (Grandal et al., 2007) and increased resistance to chemotherapeutic agents (Montgomery et al., 2000). The cell lines generated in our studies are abbreviated using conventions shown in Figure $1 A$. We further expressed firefly luciferase in all cells to be able to follow their growth in vivo by noninvasive imaging.

\section{Expression of DNp53 and EGFRvIII in O-2A/OPCs and GRP} cells causes different kinds of tumors

Transduced O-2A/OPCs and GRP cells were isografted into wildtype C57BL/6 mice to determine their ability to form tumors. Following transplantation, we found that $G^{53 E}$ or $\mathrm{O}^{53 E}$ cells both generated luciferase-expressing tumors over a period of 2-5 
A Tumors derived from mouse model

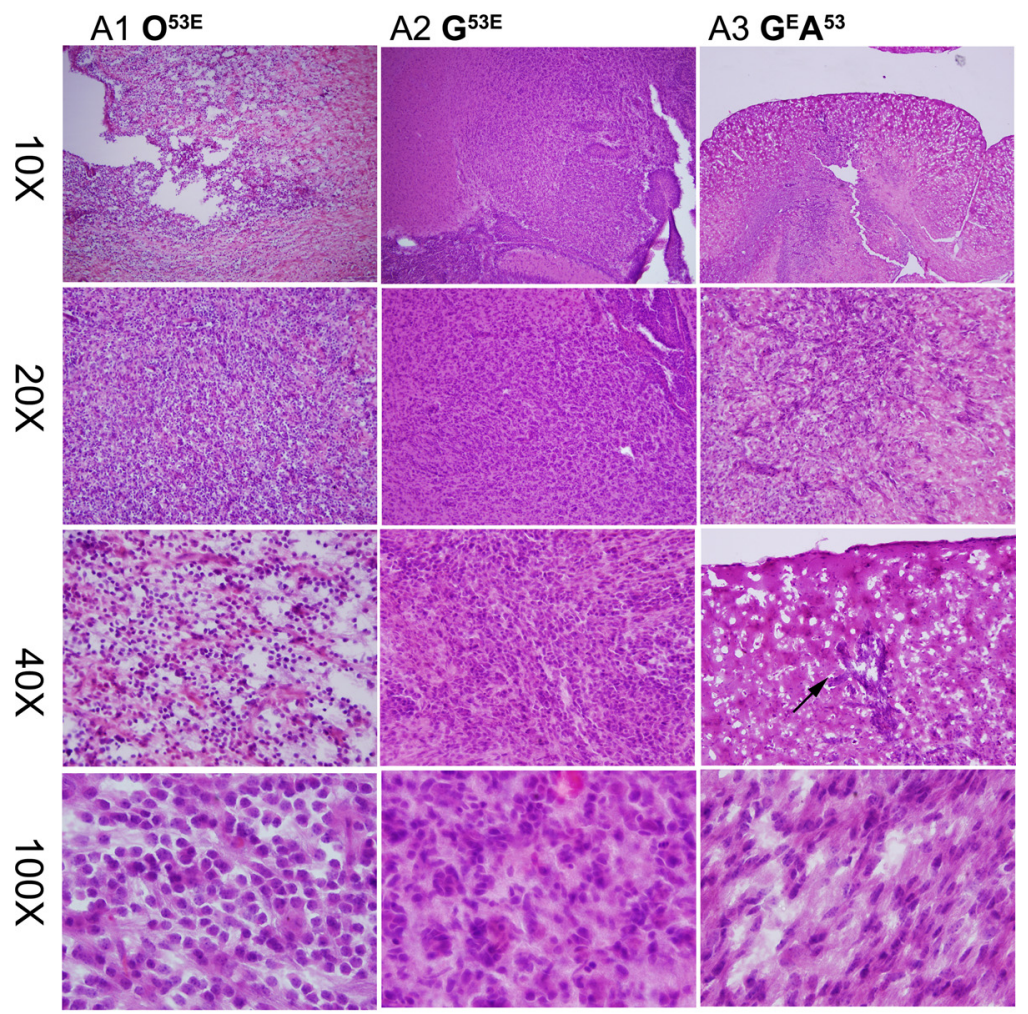

B Examples of clinical human tumors

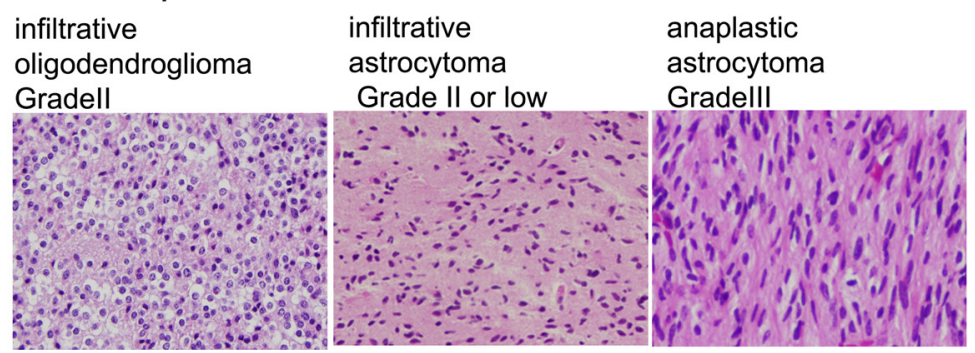

Figure 3. $\quad 0^{53 E}, \mathrm{G}^{53 E}$, and $\mathrm{G}^{E} \mathrm{~A}^{53}$ cells all form different types of tumors in vivo. $A$, H\&E staining showed that different transduced cells generated histopathologically distinct types of gliomas. $\mathbf{A 1}$, Tumors originating from $0^{53 E}$ cells appeared as sheets of rounded nuclei with arcuate blood vessels, which are cytological features commonly seen in oligodendroglial neoplasms and also in small-cell astrocytomas. $\boldsymbol{A 2}$, Tumors originating from $\boldsymbol{G}^{53 E}$ cells formed a lesion in the subventricular zone and were composed of cells with relatively uniform round and irregular nuclei, which are classified as infiltrative astrocytomas. A3, Tumors originating from $G^{E} A^{53}$ cells infiltrated around the blood vessels as shown by the arrow and were composed of cells with elongated or hyperchromatic nuclei, which are cytological features of higher grade astrocytomas. $0^{53 E}$ and $\mathrm{G}^{E} \mathrm{~A}^{53}$ cells infiltrated the normal tissues around blood vessels (Scherer's secondary structure in high-grade astrocytomas and high-grade oligodendrogliomas). The magnifications are shown on the left. $\boldsymbol{B}$, Examples of H\&E staining of clinical human anaplastic astrocytoma, anaplastic oligodendroglioma, and infiltrative astrocytoma.

weeks (Fig. 1D). In contrast, basal luciferase activity disappeared in 1-2 weeks in mice transplanted with cells expressing DNp53 together with increased levels of PDGFR $\alpha$.

$\mathrm{O}^{53 E}$ cells formed aggressive tumors, while $\mathrm{G}^{53 E}$ cells showed limited in vivo growth. Although both populations generated tumors in $2-5$ weeks in all mice engrafted with 500,000 cells, when we grafted 25,000 cells (using cells isolated from independent infection experiments), $G^{53 E}$ cells only generated tumors in $2 / 4$ mice, while $\mathrm{O}^{53 E}$ cells generated tumors in 9/9 mice (Table 1). Moreover, the extent of migration and magnitude of tumor growth was far greater for $\mathrm{O}^{53 E}$ cells than for $\mathrm{G}^{53 E}$ cells (Fig. $2 A, B$ ). In contrast, neither $\mathrm{O}^{53 P}$ cells nor $\mathrm{G}^{53 P}$ cells generated tumors in vivo (Table 1), despite the frequency of amplified PDGFR $\alpha$ expression in low-grade gliomas (Parsons et al., 2008; Verhaak et al., 2010).
$\mathrm{O}^{53 E}$ cell-derived tumors exhibited multiple features seen in high-grade human oligodendrogliomas and also in small-cell astrocytomas (Fig. 3A1). Tumor cells showed small uniformly round nuclei with a fine chromatic pattern, occasional micronucleoli, and little cytoplasm. Tumors had apparent epicenters in the nucleus accumbens and basal ganglia. Within the tumor mass, some arcuate capillaries without hyperplasia were present. We observed subependymal accumulation of $\mathrm{O}^{53 E}$ cells at the ipsilateral ventricle. We also found focal intraventricular extension of $\mathrm{O}^{53 E}$ cells without frank ependymal seeding. $\mathrm{O}^{53 E}$ cells infiltrated into the overlying cortex, the adjacent corpus callosum, parietal lobe, and the contralateral hemisphere. There were also perivascular $\mathrm{O}^{53 E}$ cells away from the epicenter in areas without tumor mass with infiltration of normal tissue around blood vessels.

In contrast, $\mathrm{G}^{53 E}$ cells generated tumors with characteristics more like those of grade II benign infiltrative astrocytomas (Fig. 3A2). Tumor cells had small round to ovoid nuclei with minimal atypia and without extensive mitotic activity. We observed small collections of tumor cells in the superior caudate/putamen subjacent to the anterior horn of the lateral ventricle, but no $\mathrm{G}^{53 E}$ cells were observed in the anterior, posterior, and ventral parts of brain (Figs. 2B, 3A2). There was no evidence of notable microglial activation or infiltration of normal tissues around blood vessels.

\section{Astrocytic differentiation can either suppress tumor-forming ability of GRP cells or enhance the malignancy of tumors, depending on the order of oncogene expression}

The ability to generate benign astrocytomas from $G^{53 E}$ cells was of particular interest in light of previous conflicting findings related to the effects of astrocytic differentiation on tumor generation. Some studies have reported that astrocyte generation can suppress differentiation, while other studies have reported conflicting results (Holland et al., 1998; Bachoo et al., 2002; Uhrbom et al., 2002; Bruggeman et al., 2007; Marumoto et al., 2009; Jacques et al., 2010; Ghazi et al., 2012). In at least some of these conflicting studies, however, experiments were conducted in such a manner that cells from mice with germline mutations in tumor suppressor genes, or targeted knockout of TP53 tumor suppressor genes in nestin-expressing cells, were transduced to express a second oncogenic change in GFAP-expressing cells. Thus, the first mutation is already present in stem and progenitor cells before expression of the second oncogene in astrocytes, which raises the question of whether prior oncogene expression at a precursor cell stage may contribute to the biology of astrocytoma generation. 
GRP cells are particularly useful in analyzing the above questions due to their ability to generate astrocytes that have been analyzed in several transplantation studies (Davies et al., 2006, 2008, 2011). Achieving an experimental manipulation in which one oncogene was introduced at the precursor cell stage and the second after differentiation was performed by introducing DNp53 or EGFRvIII at the GRP cell stage, inducing differentiation into GFAP + astrocytes, and then introducing the complementary oncogene. We also introduced DNp53 and EGFRvIII directly into purified cortical astrocytes.

Induction of astrocytic differentiation as an intermediate step between the introduction of DNp53 and EGFRvIII (i.e., $\mathrm{G}^{53} \mathrm{~A}^{E}$ cells; Fig. $1 C$ ), or expression of these oncogenes in astrocytes themselves (i.e., $\mathrm{A}^{53 E}$ cells; Fig. $1 C$ ), suppressed tumor generation in vivo compared with $\mathrm{G}^{53 E}$ cells, and transplantation of these cells was not associated with maintenance or spread of luciferase expression (Table 1). Similarly, expression of DNp53 and PDGFR $\alpha$ in astrocytes (i.e., $\mathrm{A}^{53 P}$ cells; Fig. 1C) was not associated with tumor growth.

In contrast, reversing the order in which oncogenes were expressed demonstrated that astrocyte differentiation can also promote malignancy. Rapidly growing and highly migratory tumors were generated in mice transplanted with 25,000 cells in which EGFRvIII was introduced into GRP cells, followed sequentially by induction of astrocytic differentiation and introduction of DNp53 (i.e., $\mathrm{G}^{E} \mathrm{~A}^{53}$ cells; Table 1, Figs. $1 C, 2 C, 3 A 3$ ). These tumors also grew more aggressively than $\mathrm{G}^{53 E}$ tumors.

In contrast with tumors generated from $\mathrm{O}^{53 E}$ or $\mathrm{G}^{53 E}$ cells, $\mathrm{G}^{E} \mathrm{~A}^{53}$-derived tumors most closely resembled highly malignant anaplastic astrocytomas. Tumors exhibited with an epicenter in the nucleus accumbens and basal ganglia with extension to the thalamus (Figs. 2C, 3A3). Tumor cells showed elongated or hyperchromatic nuclei with modest atypia. $G^{E} A^{53}$ cells infiltrated the corpus callosum and the overlying cortex with striking, dense angiocentric aggregation even in areas well removed from the hypercellular tumor. $\mathrm{G}^{E} \mathrm{~A}^{53}$ cells infiltrated into the parietal lobe and the deep gray matter: caudate and putamen, and infiltrated into the contralateral hemisphere through both the corpus callosum and anterior commissure. There was also subependymal but no leptomeningeal extension. In contrast with $G^{53 E}$ cells, $G^{E} A^{53}$ cells infiltrated normal tissue around blood vessels, shown as the arrow in Figure $3 A 3$.

It was also noteworthy that GRP cells were the only cells in which experiments examining the consequences of reversing the order of oncogene expression was possible, as both O-2A/OPCs and astrocytes induced to expression EGFRvIII alone were not able to undergo continued cell division.

\section{Different host cells were found in $G^{53 E}, \mathrm{O}^{53 E}$, and $\mathrm{G}^{E} \mathrm{~A}^{53}$ cell-derived tumors}

As analysis of antigen expression is an important component of tumor classification, we next examined $\mathrm{G}^{53 E}, \mathrm{O}^{53 E}$, and $\mathrm{G}^{E} \mathrm{~A}^{53}$ cell-derived tumors to determine whether the patterns of antigen expression by tumor cells correlated with the neuropathological classification of tumors. In these analyses, tumor sections were labeled with the CC1 anti-adenomatous polyposis coli protein antibody (a marker of oligodendrocytes; Kitada and Rowitch, 2006), anti-GFAP antibody (a marker of astrocytes), anti-Olig2 (a transcriptional regulator important in CNS development that is expressed by all types of gliomas), anti-LeX (a stem cell marker), anti-Ki67 (a marker of proliferating cells), and antibodies against the neuronal antigens NeuN or $\beta$-III tubulin. Tumor cells were readily identified in these analyses by expression of high
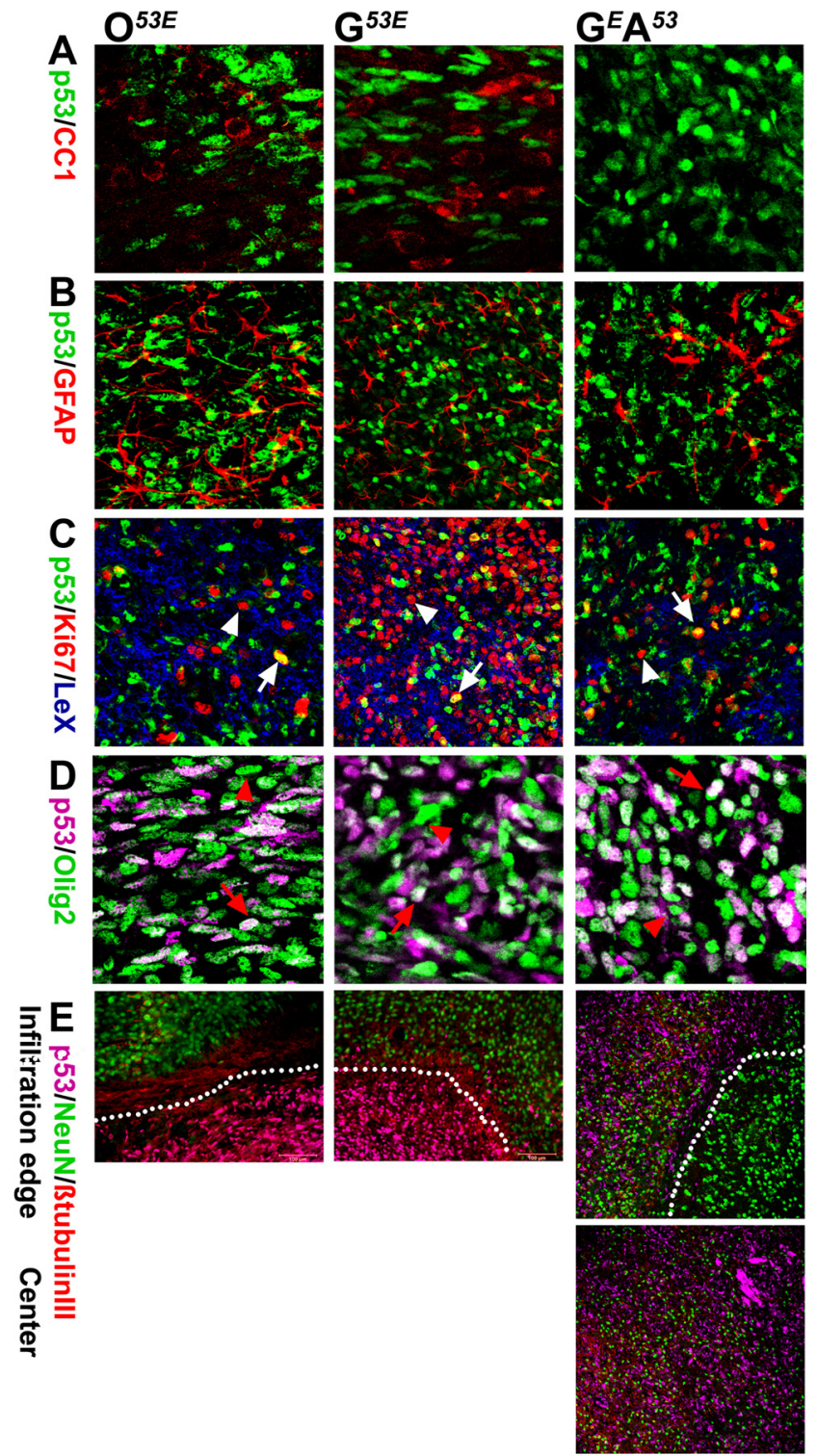

Figure 4. Analysis of antigen expression in tumors from $\mathrm{G}^{E} \mathrm{~A}^{53}, 0^{53 E}$, and $\mathrm{G}^{53 E}$ cells in vivo. $\boldsymbol{A}$, The tumors derived from $\mathrm{G}^{E} \mathrm{~A}^{53}$ cells did not contain any $\mathrm{C}(1+$ cells, but such cells were abundant in $0^{53 E}$ and $\mathrm{G}^{53 E}$-derived gliomas. No $\mathrm{CC} 1+$ cells were colabeled with anti-p53 antibodies, indicating they were of host origin. $\boldsymbol{B}$, In contrast, all tumors contained GFAP + cells, the majority of which were of host origin. $C$, All tumors also contained abundant LeX + cells and Ki67+ cells. D, All tumors also contained abundant Olig2 + cells, many of which also were labeled with anti-p53 antibody indicating them to be of tumor origin. $E$, Only $G^{E} A^{53}$-derived tumors contained abundant NeuN + cells in the tumor mass. Dotted lines represent infiltration edges of tumors. Arrows in C show TP53 +/Ki67 + cells; arrowheads show TP53-/Ki67 + cells. Arrows in D show TP53 +/0lig2 + cells; arrowheads show TP53-/0lig2 + cells.

levels of TP53 and EGFRvIII (which showed virtually complete correlation).

Tumors arising from $\mathrm{O}^{53 E}$ and $\mathrm{G}^{53 E}$ transplants contained readily detectable cells labeled with anti-adenomatous polyposis coli protein (clone CC1) antibody (a marker of oligodendrocytes; Kitada and Rowitch, 2006). As the CC1+ cells were all TP53 negative, however, such cells were host derived and not tumor derived (Fig. 4A).

In contrast with the restricted presence of $\mathrm{CC} 1+$ cells, GFAP + cells were found in all three tumor types. Even for this antigen, however, the majority of GFAP + cells were TP53 negative and thus most likely of host origin (Fig. 4B). In addition, 
Table 2. Expression of prominin (CD133) and LeX antigens varies greatly among different cell populations

\begin{tabular}{lll}
\hline Cell type & Prominin/CD133+ & SSEA-1/LeX+ \\
\hline $0^{53 E}$ & $0.38 \% \pm 0.04 \%$ & $0.23 \% \pm 0.13 \%$ \\
$0^{53 P}$ & $<1 \%$ & $<1 \%$ \\
$G^{53 E}$ & $21.32 \% \pm 7.99 \%$ & $28.33 \% \pm 12.56 \%$ \\
$G^{53 P}$ & $<1 \%$ & $<1 \%$ \\
$G^{E} A^{53}$ & $9.60 \% \pm 2.93 \%$ & $9.13 \% \pm 4.73 \%$ \\
$G^{53} A^{E}$ & $0.32 \% \pm 0.23 \%$ & $2.96 \% \pm 2.13 \%$ \\
$A^{53 E}$ & $0.76 \% \pm 0.33 \%$ & $1.21 \pm 0.54 \%$ \\
$A^{53 P}$ & $<1 \%$ & $<1 \%$ \\
\hline
\end{tabular}

The values of prominin (CD133) and LeX-expressing cells represent average percentage \pm SEM of all live cells (propidium iodide ${ }^{\text {low }}$ or DAPI ${ }^{\text {low }}$ ) of three separate FACS experiments.

tumor-derived cells positive for LeX and Olig2 (a transcriptional regulator that is expressed by all types of gliomas; Ligon et al., 2004) were found in all tumors and all tumors contained Ki67+ (i.e., dividing) cells and Olig2 + cells of both transplant and host origin (Fig. 4C,D).

$\mathrm{CC} 1+$ oligodendrocytes were not seen in $\mathrm{G}^{E} \mathrm{~A}^{53}$-derived tumors, which instead contained abundant cells expressing the neuronal markers NeuN and $\beta$-III tubulin. NeuN+ and $\beta$-III tubulin + cells were found at both the center and the infiltrating edge of $\mathrm{G}^{E} \mathrm{~A}^{53}$-derived tumors. These cells did not express TP53, suggesting that these cells were host derived (Fig. $4 E$ ). In contrast to $\mathrm{G}^{E} \mathrm{~A}^{53}$-derived tumors, $\mathrm{O}^{53 E}$ or $\mathrm{G}^{53 E}$ tumors did not contain $\mathrm{NeuN}+$ or $\beta$-III tubulin + cells. These differences were not due to analysis of different brain regions or differences in tumor size, as $G^{53 E}$ cell-derived tumors were much smaller than either $\mathrm{O}^{53 E}$ or $\mathrm{G}^{E} \mathrm{~A}^{53}$ cell-derived tumors.

The ability to generate tumors in vivo correlates with the ability to generate foci in adherent cultures, but not with expression of putative cancer stem cell antigens or the ability to grow as adhesion-independent spheroids

The differences in tumor generation among the cell types examined raised the question of whether these different cell types also exhibited differences in expression in vitro of putative markers of tumor initiating cell (TIC) capacity. The two phenotypes most often studied in this respect are expression of putative antigenic markers of TICs and the ability of cells to generate adhesionindependent spheroids in vitro. We therefore examined each of these properties.

The three putative markers of TICs that we examined were CD133 (prominin), Lewis carbohydrate antigen (LeX/CD15), and labeling with the A2B5 monoclonal antibody. CD133+ cells were originally reported to be more capable of tumor initiation than CD133-negative cells (Singh et al., 2004; Bao, 2006), but even in studies reporting that tumors with more CD133+ cells tended to be more malignant (Ogden et al., 2008; Rebetz et al., 2008; Zeppernick et al., 2008) detailed examination of the data reveals multiple malignant tumors with few CD133+ cells and multiple benign tumors with many such cells. Expression of LeX was reported to more accurately predict whether a cell can form gliomas (Son et al., 2009).

Results obtained from antigen analysis revealed that the proportion of $\mathrm{CD} 133+, \mathrm{LeX}+$, and $\mathrm{A} 2 \mathrm{~B} 5+$ cells did not correlate with the tumor-forming capacity of tumors derived directly from progenitor cells. However, the expression of CD133 and LeX showed a better correlation in the case of cell lines derived from astrocytes (Table 2). G ${ }^{53 E}$ cultures contained $\sim 21 \%$ CD133+ and $\sim 28 \%$ LeX + cells, as contrasted with expression of only $\sim 2 \%$ CD $133+$ and $<1 \%$ LeX + cells in parental GRP cultures. In

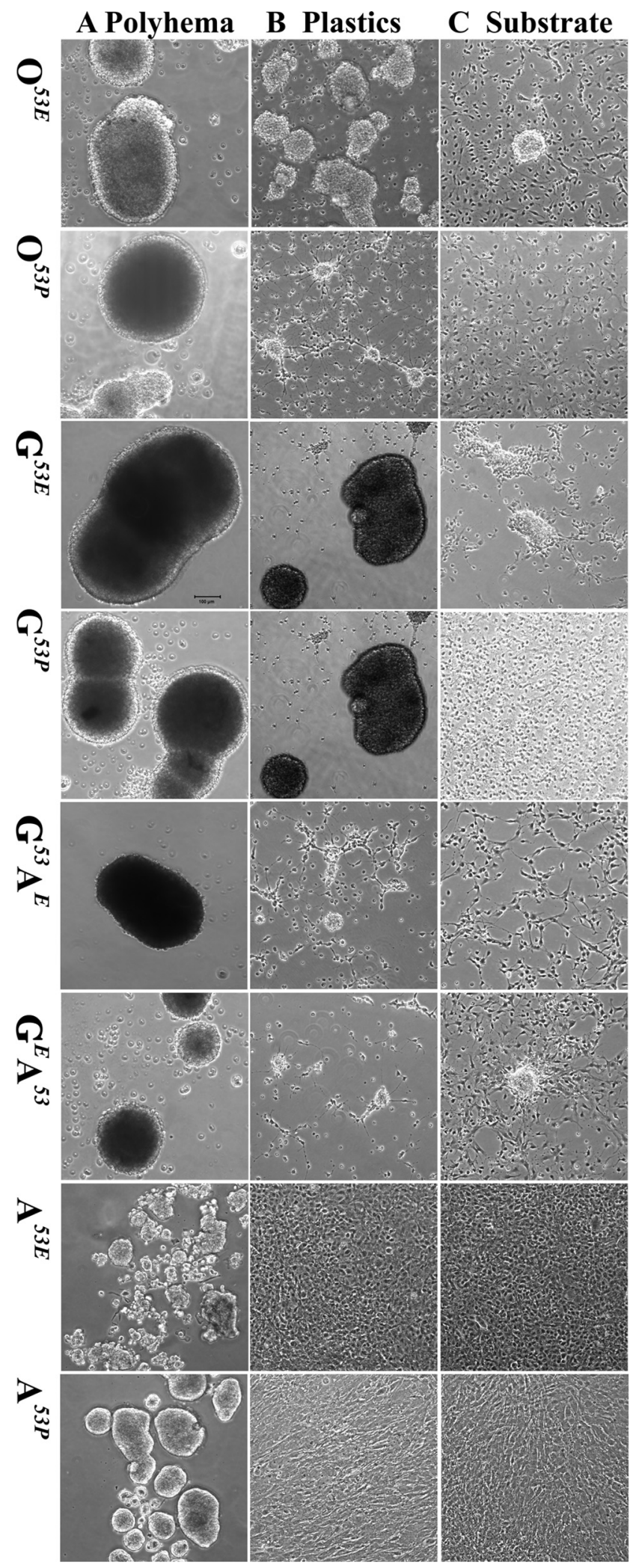

Figure 5. The ability of cells to form foci when grown on appropriate substrates predicted tumorigenicity, but generation of the adherence-independent spheroids did not. $A$, When grown on polyHEMA-coated surfaces, all cell lines generated adherence-independent spheroids. $\boldsymbol{B}$, When grown on tissue culture plastic, only populations derived from progenitors spontaneously generated spheroids ( $(\boldsymbol{C}$. When grown on substrates used for studying comparable primary cells (fibronectin and laminin for GRP cells, PLL for 0-2A/OPCs and astrocytes), only $0^{53 E},{ }^{53 E}$, and $G^{E} A^{53}$ cells generated 3D foci. Scale bar, $100 \mu \mathrm{m}$. See also Table 3. 
Table 3. Limiting dilution assays were performed to analyze the frequency of cells giving rise to free-floating spheroids (on polyHema) or 3D foci (on tissue culture plastic or on substrates used for studying primary cells)

\begin{tabular}{|c|c|c|c|c|c|c|c|c|c|}
\hline \multirow[b]{2}{*}{ Coating } & \multirow[b]{2}{*}{ Cell } & \multicolumn{8}{|c|}{ Plating density (number of cells/well) } \\
\hline & & 10 & 20 & 50 & 100 & 200 & 500 & 1000 & 2000 \\
\hline \multirow[t]{8}{*}{ PolyHEMA } & $0^{53 E}$ & $40 \%$ & $90 \%$ & $100 \%$ & $100 \%$ & $100 \%$ & $100 \%$ & $100 \%$ & $100 \%$ \\
\hline & $0^{53 P}$ & $50 \%$ & $60 \%$ & $90 \%$ & $100 \%$ & $100 \%$ & $100 \%$ & $100 \%$ & $100 \%$ \\
\hline & $G^{53 E}$ & $90 \%$ & $100 \%$ & $100 \%$ & $100 \%$ & $100 \%$ & $100 \%$ & $100 \%$ & $100 \%$ \\
\hline & $G^{53 P}$ & $50 \%$ & $70 \%$ & $100 \%$ & $100 \%$ & $100 \%$ & $100 \%$ & $100 \%$ & $100 \%$ \\
\hline & $G^{53} A^{E}$ & $90 \%$ & $100 \%$ & $100 \%$ & $100 \%$ & $100 \%$ & $100 \%$ & $100 \%$ & $100 \%$ \\
\hline & $G^{E} A^{53}$ & $100 \%$ & $100 \%$ & $100 \%$ & $100 \%$ & $100 \%$ & $100 \%$ & $100 \%$ & $100 \%$ \\
\hline & $A^{53 E}$ & 0 & 0 & 0 & $30 \%$ & $40 \%$ & $70 \%$ & $100 \%$ & $100 \%$ \\
\hline & $A^{53 P}$ & 0 & 0 & 0 & $10 \%$ & $10 \%$ & $30 \%$ & $70 \%$ & $100 \%$ \\
\hline \multirow[t]{6}{*}{ Tissue culture plastic } & $0^{53 E}$ & $80 \%$ & $100 \%$ & $100 \%$ & $100 \%$ & $100 \%$ & $100 \%$ & $100 \%$ & $100 \%$ \\
\hline & $0^{53 P}$ & $50 \%$ & $90 \%$ & $100 \%$ & $100 \%$ & $100 \%$ & $100 \%$ & $100 \%$ & $100 \%$ \\
\hline & $G^{53 E}$ & $100 \%$ & $100 \%$ & $100 \%$ & $100 \%$ & $100 \%$ & $100 \%$ & $100 \%$ & $100 \%$ \\
\hline & $G^{53 P}$ & $50 \%$ & $100 \%$ & $100 \%$ & $100 \%$ & $100 \%$ & $100 \%$ & $100 \%$ & $100 \%$ \\
\hline & $G^{53} A^{E}$ & $90 \%$ & $100 \%$ & $100 \%$ & $100 \%$ & $100 \%$ & $100 \%$ & $100 \%$ & $100 \%$ \\
\hline & $G^{E} A^{53}$ & $80 \%$ & $100 \%$ & $100 \%$ & $100 \%$ & $100 \%$ & $100 \%$ & $100 \%$ & $100 \%$ \\
\hline \multirow[t]{3}{*}{ Substrate } & $0^{53 E}$ & $17 \%$ & $67 \%$ & $83 \%$ & $100 \%$ & $100 \%$ & $100 \%$ & $100 \%$ & $100 \%$ \\
\hline & $G^{53 E}$ & $83 \%$ & $100 \%$ & $100 \%$ & $100 \%$ & $100 \%$ & $100 \%$ & $100 \%$ & $100 \%$ \\
\hline & $G^{E} A^{53}$ & $50 \%$ & $67 \%$ & $100 \%$ & $100 \%$ & $100 \%$ & $100 \%$ & $100 \%$ & $100 \%$ \\
\hline
\end{tabular}

Cell dilutions ranged from 10 cells/well to 2000 cells/well in $100 \mu$ l aliquots. After $7 \mathrm{~d}$, the fraction of wells containing free-floating spheroids or 3D foci for each cell plating density was calculated.

contrast, the more malignant $\mathrm{O}^{53 E}$ cells looked much like their parental cells, with $<0.5 \%$ of oncogene-expressing cells being $\mathrm{CD} 133+$ or LeX + , much as parental O2A/OPC cultures contained almost no CD133+ or LeX + cells. When we examined labeling with the $\mathrm{A} 2 \mathrm{~B} 5$ antibody (which also has been reported as a marker of glioma cells with TIC-like properties; Ogden et al., 2008; Auvergne et al., 2013), we found that $>99.5 \%$ of $\mathrm{G}^{53 E}$ and $\mathrm{O}^{53 E}$ cells were $\mathrm{A} 2 \mathrm{~B} 5+$, as is the case for their parental primary cells.

Expression of CD133 and LeX expression in astrocytes depended on when DNp53 and EGFRvIII were introduced, with tumorigenic cultures showing the highest level of expression of these markers. Very few cells expressed CD133 or LeX in primary astrocyte cultures, and only $\sim 1 \%$ of cells were CD $133+$ or LeX+ in $\mathrm{A}^{53 E}$ cultures. $\mathrm{G}^{53} \mathrm{~A}^{E}$ cultures also contained few CD133+ cells $(0.3 \%)$ or $3 \%$ LeX + cells $(3 \%)$. In contrast, in $G^{E} A^{53}$ cell cultures (i.e., cells in which EGFRvIII was introduced into GRP cells, and DNp53 was introduced after induction of astrocyte generation), $\sim 9 \%$ of cells were CD133+ or LeX + . The different proportions of cells expressing these antigens were not simply due to growth in different conditions, as $\mathrm{G}^{53 E}, \mathrm{G}^{53} \mathrm{~A}^{E}$, and $\mathrm{G}^{E} \mathrm{~A}^{53}$ cells were all grown in identical conditions.

In contrast with the effects of coexpression of DNp53 and EGFRvIII in GRP cells and their derivatives, coexpression of DNp53 and PDGFR $\alpha$ did not increase the expression of CD133 or LeX in GRP cells, O-2A/OPCs, or astrocytes (Table 2).

When we examined the capacity of the various cell lines under study to grow as free-floating spheroids, which has been suggested as a predictor of clinical outcome and tumor progression (Beier et al., 2008; Laks et al., 2009) and a means of enriching to TIC-like cells (Galli et al., 2004; Singh et al., 2004), we found no correlation with tumorigenicity. On nonadhesive surfaces coated with PolyHEMA, all cell lines were able to grow as free-floating spheroids (Fig. 5,A), although the efficiency of spheroid generation varied between different starting populations (Table 3 ). When we examined our three tumor-forming populations, we found that $\mathrm{O}^{53 E}$ cells (which generated malignant tumors) were able to generate freefloating spheroids in all wells of 96-well plates at the plating density of 50 cells/well. $\mathrm{G}^{53 E}$ cells (which formed benign tumors) generated spheroids at a lower plating density of 20 cells/well while $\mathrm{G}^{E} \mathrm{~A}^{53}$ cells (which formed malignant tumors) were able to grow as free-floating spheroids in all wells at the somewhat lower plating density of 10 cells/well. These efficiencies of spheroid generation also did not discriminate nontumorigenic populations as $\mathrm{G}^{53} \mathrm{~A}^{E}$ cells (which did not form tumors) also generated spheroids at plating densities of 20 cells/well and $\mathrm{G}^{53 P}$ cells (which did not form tumors) generated spheroids in all wells at plating densities of 50 cells/well. Thus, although some populations that did not generate tumors required higher plating densities to generate spheroids $\left(\mathrm{O}^{53 P}\right.$ cells $=100$ cells $/$ well; $\mathrm{A}^{53 E}$ cells $=1000$ cells $/$ well; $\mathrm{A}^{53 P}$ cells $=2000$ cells/well), this particular phenotype did not discriminate between tumorigenic and nontumorigenic populations. Growth on tissue culture plastic also did not discriminate between tumorigenic and nontumorigenic populations, although only cell lines initiated from precursor cells generated these three-dimensional aggregates when grown on these surface (Fig. 5B).

The one condition in which patterns of growth correlated precisely with the ability of cells to generate tumors was when cells were grown on substrates used for studying their primary counterparts (Fig. 5,C, Table 3). O-2A/OPCs can be grown on surfaces coated with PLL or with fibronectin/laminin, and $\mathrm{O}^{53 E}$ cells were able to generate 3D foci when plated at 100 cells/well on PLL-coated surfaces (Fig. 5) or fibronectin/laminin-coated surfaces (data not shown). Primary GRP cells require growth on fibronectin/laminin-coated surfaces, and while $\mathrm{G}^{E} \mathrm{~A}^{53}$ cells generated foci on these surfaces at plating densities as low as 50 cells/well, they did not do so on PLL-coated surfaces. When grown on PLL-coated surfaces, $G^{53 E}$ cells were able to form dense aggregates, but these did not express the $3 \mathrm{D}$ foci-like appearance seen when these cells were grown on surfaces coated with fibronectin/laminin (even at plating densities as low as 20 cells/ well). In contrast, $\mathrm{G}^{53} \mathrm{~A}^{E} \mathrm{~A}^{53 E}, \mathrm{O}^{53 P}, \mathrm{G}^{53 P}$, or $\mathrm{A}^{53 P}$ cells did not generate $3 \mathrm{D}$ foci on any surfaces.

The ability of $\mathrm{O}^{53 E}, \mathrm{G}^{53 E}$, and $\mathrm{G}^{E} \mathrm{~A}^{53}$ cells to generate $3 \mathrm{D}$ foci was not altered by reducing substrate concentrations over an eightfold range (data not shown). $\mathrm{O}^{53 E}$ cells grew as $3 \mathrm{D}$ foci on surfaces coated with serial dilutions of PLL (1:2; 1:4; and 1:8). Similarly, when $\mathrm{G}^{53 E}$ and $\mathrm{G}^{E} \mathrm{~A}^{53}$ cells were plated on surfaces coated with serial dilutions of fibronectin/laminin (1:2; 1:4; and 
1:8), both cell types formed 3D foci, with the only difference being that there were fewer monolayer cells when $\mathrm{G}^{53 E}$ and $\mathrm{G}^{E} \mathrm{~A}^{53}$ cells were plated on surfaces coated with diluted fibronectin/ laminin solutions.

GRP cells and O-2A/OPCs show differences in their acquisition of resistance to $\mathrm{BCNU}$, and resistance is further enhanced in $G^{E} A^{53}$ cells

We next examined whether the cell-of-origin of a tumor also may be important in contributing to resistance to chemotherapy. As TP53 and EGFR mutations both can confer resistance to chemotherapeutic agents (Buttitta et al., 1997; Montgomery et al., 2000; Fraser et al., 2003; Cosse et al., 2009), we would expect all tumorigenic populations to be more resistant than the cells of origin. In these analyses, we focused on sensitivity to carmustine (BCNU), a nitrosourea used in treatment of oligodendrogliomas and other brain tumors, which is highly toxic for O-2A/OPCs and GRP cells but less so for astrocytes (Dietrich et al., 2006).

We found that although primary O-2A/OPCs and GRP cells were similarly sensitive to BCNU, $\mathrm{G}^{53 E}$ cells were more BCNU resistant than $\mathrm{O}^{53 E}$ cells (Fig. 6). For example, exposure to $25 \mu \mathrm{M}$ BCNU killed $>90 \%$ of primary O-2A/OPCs and GRP cells. In contrast, the killing of $>90 \%$ of $\mathrm{O}^{53 E}$ cells required $100 \mu \mathrm{M}$ BCNU, but this exposure level only killed $\sim 40 \%$ of $\mathrm{G}^{53 E}$ cells (Fig. 6 A). Even exposure to $500 \mu \mathrm{M}$ BCNU killed only $\sim 60 \%$ of $\mathrm{G}^{53 E}$ cells (Fig. $6 B$ ).

Resistance to BCNU in the GRP cell lineage increased still further if astrocytic differentiation was induced between expression of DNp53 and EGFRvIII. At low exposure levels, both cell types showed similar resistance. When exposure levels were increased, however, $\mathrm{G}^{E} \mathrm{~A}^{53}$ cells showed greater resistance such that exposure levels of $500 \mu \mathrm{M}$ and $1 \mathrm{~mm}$ BCNU killed more $\mathrm{G}^{53 E}$ cells than $\mathrm{G}^{E} \mathrm{~A}^{53}$ cells (Fig. 6B).

As it is generally believed that rapidly dividing cells are more susceptible to chemotherapeutic agents than slowly dividing cells, we determined whether such differences in division correlated with vulnerability in our experiments. However, we found that the more susceptible $\mathrm{O}^{53 E}$ cultures contained fewer cells labeled with the Ki67 antibody (a marker of proliferating cells) than $\mathrm{G}^{53 E}$ and $\mathrm{G}^{E} \mathrm{~A}^{53}$ cultures (Fig. $6 \mathrm{C}$ ). These results suggest the difference in the response of tumorigenic glial precursor cells to $\mathrm{BCNU}$ was not simply due to more rapid division by $\mathrm{O}^{53 E}$ cells.

\section{Discussion}

The extensive interest in identifying cells of origin for different gliomas is based on the hypothesis that cellular origin has important consequences for glioma biology. It is, however, equally possible-particularly for closely related cells-that tumor phenotype is primarily determined by the specific oncogenes expressed, particularly as different kinds of tumors tend to have different genetic alterations. Answering this question requires expression of identical oncogenes in different cell types that are sufficiently closely related that divergent outcomes would not be easily predicted. GRP cells and O-2A/OPCs are particularly attractive for studying this problem as they are both well characterized CNS progenitor cells that are restricted to the generation of glia and that can also be isolated and studied as highly purified ( $>99.5 \%)$ cell populations. Analysis of these cells offers multiple new findings (summarized in Table 4) related to potential contributions of cell-of-origin to tumor phenotype.

One striking difference between GRP cells and O-2A/OPCs was seen in the cytologically distinct tumors they generated, with GRP cells generating tumors with characteristics of astrocytomas
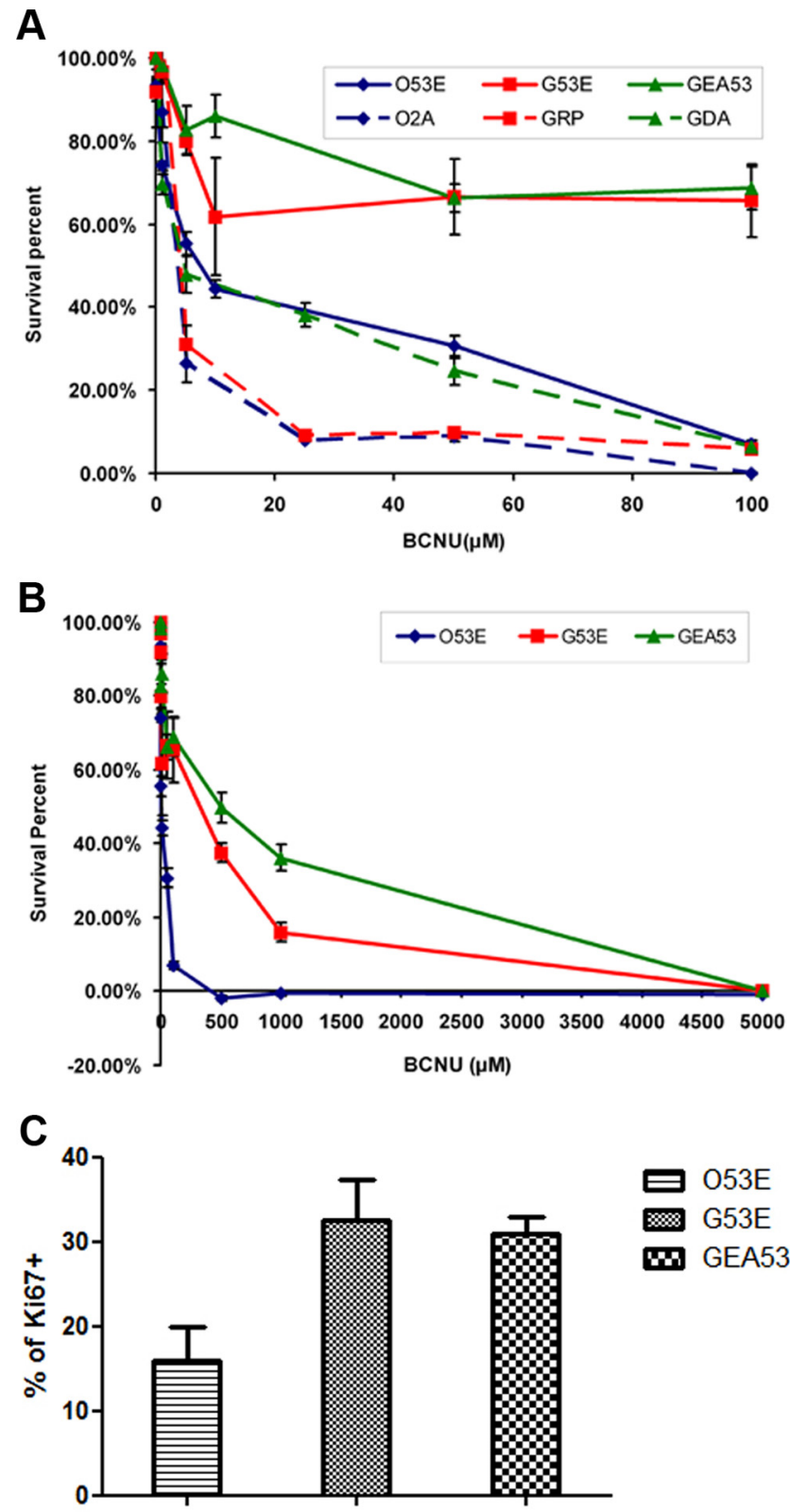

Figure 6. Resistance to $B C N U$ is correlated with the tumor cell-of-origin. $A$, Dose-response analysis for effects of $B C N U$ on wild-type GRP cells, 0 -2A progenitor cells, and astrocytes (dotted lines) and $0^{53 E}, G^{53 E}$, and $G^{E} A^{53}$ cells (solid lines) shows that expression of DNp53 and EGFRvill is associated with different levels of chemoresistance in the different cell lines. $\boldsymbol{B}$, Analysis at higher BCNU levels further confirms different levels of resistance in the different cell lines. Cells were exposed to BCNU for $1 \mathrm{~h}$ and survival was determined after an additional $48 \mathrm{~h}$. Data are shown as Mean \pm SEM normalized to control values $(n=6$ for each condition in two independent experiments). C, Determination of the percentage of Ki67+ cells in $0^{53 E}, G^{53 E}$, and $G^{E} A^{53}$ cell cultures shows that the more susceptible $0^{53 E}$ cells contained fewer Ki67+ cells than cultures of $\mathrm{G}^{53 E}$ or $\mathrm{G}^{E} \mathrm{~A}^{53}$ cells $(n=4)$.

and $\mathrm{O}-2 \mathrm{~A} / \mathrm{OPCs}$ generating tumors with characteristics shared by malignant oligodendrogliomas and small-cell astrocytomas (Perry et al., 2004). While several studies have been interpreted as indicating that $\mathrm{O}-2 \mathrm{~A} / \mathrm{OPCs}$ are ancestors of oligodendrogliomas (Weiss et al., 2003; Lindberg et al., 2009; Persson et al., 2010), these studies used promoters (CNPase, S100- $\beta$ ) expressed also in other cell types, including GRP cells (Liu et al., 2002; Wu et al., 2003). That expression of identical oncogenes in GRP cells did not generate tumors with such cytological characteristics strengthens the view that $\mathrm{O}-2 \mathrm{~A} / \mathrm{OPCs}$ may be a singular ancestor 
Table 4. Summary of the phenotypes of transformed cells in vitro, and the tumors they generated in vivo

\begin{tabular}{|c|c|c|c|c|c|c|c|c|c|c|}
\hline \multirow[b]{2}{*}{$\begin{array}{l}\text { Cell } \\
\text { type }\end{array}$} & \multicolumn{5}{|l|}{ In vitro analyses } & \multicolumn{5}{|l|}{ In vivo analyses } \\
\hline & $\begin{array}{l}\text { Spheroid formation } \\
\text { on nonadherent } \\
\text { surface }\end{array}$ & $\begin{array}{l}\text { Spheroid formation } \\
\text { on uncoated } \\
\text { plastics }\end{array}$ & $\begin{array}{l}\text { Foci formation } \\
\text { on substrate }\end{array}$ & CD133 expression & $\begin{array}{l}\text { SSEA-1/LeX } \\
\text { expression }\end{array}$ & $\begin{array}{l}\text { Tumor } \\
\text { incidence } \\
\text { ( } 25 \mathrm{~K} \text { cells/mouse) }\end{array}$ & $\begin{array}{l}\text { Closest tumor } \\
\text { classification }\end{array}$ & Tumor grade & $\begin{array}{l}\text { Malignant } \\
\text { or benign }\end{array}$ & $\begin{array}{l}\text { Types of host } \\
\text { cells in tumors }\end{array}$ \\
\hline $0^{53 E}$ & + & + & + & $0.38 \% \pm 0.04 \%$ & $0.23 \% \pm 0.13 \%$ & $100 \%$ & $\begin{array}{l}\text { Infiltrative } \\
\quad \text { oligodendroglioma }\end{array}$ & $\|$ & Malignant & $\begin{array}{l}\text { Astrocytes, } \\
\quad \text { oligodendrocytes }\end{array}$ \\
\hline $0^{53 P}$ & + & + & - & $<1 \%$ & $<1 \%$ & 0 & NT & NT & NT & NT \\
\hline$G^{53 E}$ & + & + & + & $21.32 \% \pm 7.99 \%$ & $28.33 \% \pm 12.56 \%$ & $50 \%$ & $\begin{array}{l}\text { Infiltrative } \\
\text { astrocytoma }\end{array}$ & Low grade (II) & Benign & $\begin{array}{l}\text { Astrocytes, } \\
\text { oligodendrocytes }\end{array}$ \\
\hline$G^{53 P}$ & + & + & - & $<1 \%$ & $<1 \%$ & 0 & NT & NT & NT & NT \\
\hline$G^{53} A^{E}$ & + & + & - & $0.32 \% \pm 0.23 \%$ & $2.96 \% \pm 2.13 \%$ & 0 & NT & NT & NT & NT \\
\hline$G^{E} A^{53}$ & + & + & + & $9.60 \% \pm 2.93 \%$ & $9.13 \% \pm 4.73 \%$ & $100 \%$ & $\begin{array}{l}\text { Anaplastic } \\
\text { astrocytoma }\end{array}$ & III & Malignant & $\begin{array}{l}\text { Astrocytes, } \\
\text { neurons }\end{array}$ \\
\hline$A^{53 E}$ & + & - & - & $0.76 \% \pm 0.33 \%$ & $1.21 \pm 0.54 \%$ & 0 & NT & NT & NT & NT \\
\hline$A^{53 P}$ & + & - & - & $<1 \%$ & $<1 \%$ & 0 & NT & NT & NT & NT \\
\hline
\end{tabular}

The values represent average percentage \pm SEM of all live cells of three separate experiments. + indicates that the phenotype was observed; - indicates that the phenotype was not observed. NT, No tumors.

of tumors with oligodendroglioma-like features. While the generation of benign astrocytomas from $\mathrm{G}^{53 E}$ cells raises the question of why only malignant oligodendrogliomas were seen in TPp53-/- mice expressing constitutively active v-erbB under control of the $\mathrm{S} 100 \beta$ promoter (Weiss et al., 2003; Lindberg et al., 2009; Persson et al., 2010), it may have been that more benign tumors went unnoticed in the background of the malignant tumors that were the focus of these studies.

Analysis of GRP cells also enabled novel findings regarding effects of astrocytic differentiation on glioma biology, and demonstrates that the question of whether astrocytes can be a source of gliomas is more complex than it superficially appears. Previous studies have been contradictory as to whether being an astrocyte allows transformation (Bachoo et al., 2002; Uhrbom et al., 2002), suppresses the effects of oncogenic changes seen in gliomas (Holland et al., 1998; Marumoto et al., 2009; Jacques et al., 2010), or enhances tumor formation and/or malignancy (Bruggeman et al., 2007; Ghazi et al., 2012). Our studies indicate these varied outcomes may reflect both the cell-of-origin and the sequence of oncogene expression. In both $\mathrm{A}^{53 E}$ and $\mathrm{G}^{53} \mathrm{~A}^{E}$ cells, astrocytic differentiation suppressed transformation. In contrast, reversing the order of oncogene acquisition, in $\mathrm{G}^{E} \mathrm{~A}^{53}$ cells, demonstrated that astrocyte differentiation also could enhance malignancy.

The finding that astrocytic differentiation of GRP cells expressing a single oncogene before introducing a second genetic change caused marked changes in glioma phenotypes also indicates that analyses of the cell-of-origin of gliomas need to consider possible effects of oncogene acquisition at different stages in a developmental progression. Although $G^{53 E}$-derived benign astrocytomas were unambiguously derived from GRP cells, labeling $\mathrm{G}^{E} \mathrm{~A}^{53}$-derived anaplastic astrocytomas as derived singularly from either GRP cells or astrocytes is not informative as genetic modification at both stages, and with a particular order of oncogene acquisition, was critical in generating more malignant tumors. The importance of distinguishing between the cell of initial mutation and the cell of tumor origin recently was emphasized in double-mosaic analyses on the potential role of O-2A/OPCs as a source of gliomas (Liu et al., 2011), and is also relevant to previous demonstrations of tumor generation from astrocytes that used transgenic mice in which at least one genetic change was present in stem/progenitor cells before astrocytes were generated (Holland et al., 2000; Bachoo et al., 2002; Uhrbom et al., 2002; Ghazi et al., 2012).

A further novel finding was the discovery that related tumors can contain very different host cell populations. While it is well appreciated that tumors contain host cells of various types, our finding that $\mathrm{O}^{53 E}$ cell- and $\mathrm{G}^{53 E}$ cell-derived tumors contained abundant host oligodendrocytes while $\mathrm{G}^{E} \mathrm{~A}^{53}$-derived tumors contained abundant host neurons offers a novel way in which the cell-of-origin may contribute to tumor characteristics. Such results also underscore the challenges inherent in trying to define tumor ancestry based on analysis of antigen or mRNA expression in tumor biopsies, which have rich-but potentially differenthost cell contributions.

That expression of the same oncogenes in closely related progenitor cells also was associated with striking differences in CD133 and LeX expression may help to explain otherwise puzzling outcomes regarding putative antigenic markers of TICs. The original findings that glioma TICs express CD133 (Singh et al., 2009) were followed by studies claiming this is not true for all gliomas (for review, see Beier and Beier, 2011; Donovan and Pilkington, 2012). Even studies claiming an association between the proportion of CD133 + cells in a tumor and the degree of malignancy (Rebetz et al., 2008; Zeppernick et al., 2008) include malignant tumors with few CD133 + cells and benign tumors with many CD133 + cells. Similarly, in our studies, a $>25$-fold higher proportion of CD133+ and LeX + cells in $\mathrm{G}^{53 E}$ than $\mathrm{O}^{53 E}$ cultures was associated with lesser malignancy. Increased representation of CD133+ and LeX + cells was, however, associated with greater malignancy in astrocyte-derived tumors, raising the possibility that the value of these antigens as a diagnostic tool is determined by the tumor cell-of-origin.

The differing effects of expression of DN-p53 and EGFRvIII on BCNU resistance in GRP cells and O-2A/OPCs were also of particular interest. While both primary cells were equally sensitive to $\mathrm{BCNU}$, the degree of resistance conferred was greater for $\mathrm{G}^{53 E}$ than for $\mathrm{O}^{53 E}$ cells even though Ki67 labeling indicated that the more sensitive $\mathrm{O}^{53 E}$ cells were the less extensively dividing population. Thus, although both of these oncogenes confer resistance to chemotherapeutic agents (Buttitta et al., 1997; Montgomery et al., 2000; Fraser et al., 2003; Cosse et al., 2009), the extent of resistance also seems to be modified by the origin of the glioma-forming cells.

Although previous studies have not examined the range of the properties we analyzed, some reports do indicate that different cells of origin can respond to identical genetic changes by generating different tumors. For example, expression of mutant $\mathrm{N}$-myc in perinatal cerebellar or brainstem NSCs yielded primitive neuroectodermal tumors while expression in forebrain NSCs yielded diffuse gliomas (Swartling et al., 2012). In other studies, expression of oncogenic K-ras in p53-/- astrocytes yielded aggressive tumors with giant-cell histology while NSC-derived tu- 
mors in these mice showed multilineage antigen expression and were less malignant. In these studies, however, the precise target of oncogene action is unknown as genetic changes were present throughout life and also were sufficiently widely expressed as to induce skin abnormalities, skin tumors, marked seizures, and limb paralysis (Ghazi et al., 2012). In addition, overexpression of PDGF-B in nestin-expressing cells versus GFAP-expressing cells caused different types of gliomas (Dai et al., 2001), but the expression of nestin in all progenitor cells and also in astrocytes in some conditions (Clarke et al., 1994; Almazán et al., 2001; Milosevic and Goldman, 2002; Yoo et al., 2005) means that the cell types from which tumors were derived cannot be unambiguously defined.

The reasons why expression of identical oncogenes causes diverse effects in different cells is unknown. One attractive possibility is that this reflects the diverse roles played by specific regulatory elements in different cells in a developmental sequence. The strategies we used would be particularly useful in analyzing this possibility, by allowing side-by-side comparison of primary cells and transformed derivatives. Multiple other questions in glioma biology also appear to be more accessible with these techniques, including analysis of whether expressing different oncogenes in a single cell type causes different kinds of tumors. Moreover, the ease with which this approach provided new tumor models with characteristics of diffuse infiltrative astrocytomas, anaplastic astrocytomas, and shared characteristics of malignant oligodendrogliomas and small-cell astrocytomas suggests this experimental strategy offers great potential for generating new glioma models.

Direct expression of oncogenes in highly purified cell populations can be readily extended to other CNS cells (or cells in other tissues), while other approaches used in studying the contributions of the cell-of-origin to tumor biology will always necessarily lag behind the field of cell discovery in providing access to new cell types, let alone to subpopulations of individual cell types (as occurs, for example, for GRP cells and O-2A/OPCs; Power et al., 2002; Strathmann et al., 2007). Moreover, this is the only approach that enables such analyses in human cells. Further exploration of this strategy in the CNS seems likely to enable generation of well defined tumor models that mirror the broad diversity seen in human gliomas while deepening our understanding of these tumors, while extension of this approach to other tissues will facilitate elucidation of the biological principles underlying cell-of-origin contributions to tumor phenotype.

\section{References}

Alcantara Llaguno S, Chen J, Kwon CH, Jackson EL, Li Y, Burns DK, AlvarezBuylla A, Parada LF (2009) Malignant astrocytomas originate from neural stem/progenitor cells in a somatic tumor suppressor mouse model. Cancer Cell 15:45-56. CrossRef Medline

Almazán G, Vela JM, Molina-Holgado E, Guaza C (2001) Re-evaluation of nestin as a marker of oligodendrocyte lineage cells. Microsc Res Tech 52:753-765. CrossRef Medline

Auvergne RM, Sim FJ, Wang S, Chandler-Militello D, Burch J, Fanek YA, Davis D, Benraiss A, Walter K, Achanta P, Johnson M, QuinonesHinojosa A, Natesan S, Ford HL, Goldman SA (2013) Transcriptional differences between normal and glioma-derived glial progenitor cells identify a core set of dysregulated genes. Cell Reports 3:2127-2141. CrossRef Medline

Bachoo RM, Maher EA, Ligon KL, Sharpless NE, Chan SS, You MJ, Tang Y, DeFrances J, Stover E, Weissleder R, Rowitch DH, Louis DN, DePinho RA (2002) Epidermal growth factor receptor and Ink4a/Arf: convergent mechanisms governing terminal differentiation and transformation along the neural stem cell to astrocyte axis. Cancer Cell 1:269-277. CrossRef Medline
Bao S, Wu Q, McLendon RE, Hao Y, Shi Q, Hjelmeland AB, Dewhirst MW, Bigner DD, Rich JN (2006) Glioma stem cells promote radioresistance by preferential activation of the DNA damage response. Nature 444:756760. CrossRef Medline

Beier CP, Beier D (2011) CD133 negative cancer stem cells in glioblastoma. Front Biosci 3:701-710. CrossRef Medline

Beier D, Wischhusen J, Dietmaier W, Hau P, Proescholdt M, Brawanski A, Bogdahn U, Beier CP (2008) CD133 expression and cancer stem cells predict prognosis in high-grade oligodendroglial tumors. Brain Pathol 18:370-377. CrossRef Medline

Bruggeman SW, Hulsman D, Tanger E, Buckle T, Blom M, Zevenhoven J, van Tellingen O, van Lohuizen M (2007) Bmil controls tumor development in an Ink4a/Arf-independent manner in a mouse model for glioma. Cancer Cell 12:328-341. CrossRef Medline

Buttitta F, Marchetti A, Gadducci A, Pellegrini S, Morganti M, Carnicelli V, Cosio S, Gagetti O, Genazzani AR, Bevilacqua G (1997) p53 alterations are predictive of chemoresistance and aggressiveness in ovarian carcinomas: a molecular and immunohistochemical study. Br J Cancer 75:230235. CrossRef Medline

Clarke SR, Shetty AK, Bradley JL, Turner DA (1994) Reactive astrocytes express the embryonic intermediate neurofilament nestin. Neuroreport 5:1885-1888. CrossRef Medline

Cosse JP, Ronvaux M, Ninane N, Raes MJ, Michiels C (2009) Hypoxiainduced decrease in p53 protein level and increase in c-jun DNA binding activity results in cancer cell resistance to etoposide. Neoplasia 11:976986. Medline

Dai C, Celestino JC, Okada Y, Louis DN, Fuller GN, Holland EC (2001) PDGF autocrine stimulation dedifferentiates cultured astrocytes and induces oligodendrogliomas and oligoastrocytomas from neural progenitors and astrocytes in vivo. Genes Dev 15:1913-1925. CrossRef Medline

Davies JE, Pröschel C, Zhang N, Noble M, Mayer-Pröschel M, Davies SJA (2008) Transplanted astrocytes derived from BMP or CNTF treated glial restricted precursors have opposite effects on recovery and allodynia after spinal cord injury. J Biol 7:24. CrossRef Medline

Davies JE, Huang C, Proschel C, Noble M, Mayer-Proschel M, Davies SJ (2006) Astrocytes derived from glial-restricted precursors promote spinal cord repair. J Biol 5:7. CrossRef Medline

Davies SJ, Shih CH, Noble M, Mayer-Proschel M, Davies JE, Proschel C (2011) Transplantation of specific human astrocytes promotes functional recovery after spinal cord injury. PLoS ONE 6:e17328. CrossRef Medline

Dietrich J, Han R, Yang Y, Mayer-Pröschel M, Noble M (2006) CNS progenitor cells and oligodendrocytes are targets of chemotherapeutic agents in vitro and in vivo. J Biol 5:22. CrossRef Medline

Donovan LK, Pilkington GJ (2012) CD133: holy of grail of neuro-oncology or promiscuous red-herring? Cell Prolif 45:527-537. CrossRef Medline

Fraser M, Leung B, Jahani-Asl A, Yan X, Thompson WE, Tsang BK (2003) Chemoresistance in human ovarian cancer: the role of apoptotic regulators. Reprod Biol Endocrinol 1:66. CrossRef Medline

Friedmann-Morvinski D, Bushong EA, Ke E, Soda Y, Marumoto T, Singer O, Ellisman MH, Verma IM (2012) Dedifferentiation of neurons and astrocytes by oncogenes can induce gliomas in mice. Science 338:10801084. CrossRef Medline

Galli R, Binda E, Orfanelli U, Cipelletti B, Gritti A, De Vitis S, Fiocco R, Foroni C, Dimeco F, Vescovi A (2004) Isolation and characterization of tumorigenic, stem-like neural precursors from human glioblastoma. Cancer Res 64:7011-7021. CrossRef Medline

Ghazi SO, Stark M, Zhao Z, Mobley BC, Munden A, Hover L, Abel TW (2012) Cell of origin determines tumor phenotype in an oncogenic Ras/ p53 knockout transgenic model of high-grade glioma. J Neuropathol Exp Neurol 71:729-740. CrossRef Medline

Grandal MV, Zandi R, Pedersen MW, Willumsen BM, van Deurs B, Poulsen HS (2007) EGFRvIII escapes down-regulation due to impaired internalization and sorting to lysosomes. Carcinogenesis 28:1408-1417. CrossRef Medline

Gregori N, Pröschel C, Noble M, Mayer-Pröschel M (2002) The tripotential glial-restricted precursor (GRP) cell and glial development in the spinal cord: generation of bipotential oligodendrocyte-type-2 astrocyte progenitor cells and dorsal-ventral differences in GRP cell function. J Neurosci 22:248-256. Medline 
Groves AK, Barnett SC, Franklin RJ, Crang AJ, Mayer M, Blakemore WF, Noble M (1993) Repair of demyelinated lesions by transplantation of purified O-2A progenitor cells. Nature 362:453-455. CrossRef Medline

Han R, Yang YM, Dietrich J, Luebke A, Mayer-Pröschel M, Noble M (2008) Systemic 5-fluorouracil treatment causes a syndrome of delayed myelin destruction in the central nervous system. J Biol 7:12. CrossRef Medline

Herrera J, Yang H, Zhang SC, Proschel C, Tresco P, Duncan ID, Luskin M, Mayer-Proschel M (2001) Embryonic-derived glial-restricted precursor cells (GRP cells) can differentiate into astrocytes and oligodendrocytes in vivo. Exp Neurol 171:11-21. CrossRef Medline

Holland EC, Hively WP, DePinho RA, Varmus HE (1998) A constitutively active epidermal growth factor receptor cooperates with disruption of G1 cell-cycle arrest pathways to induce glioma-like lesions in mice. Genes Dev 12:3675-3685. CrossRef Medline

Holland EC, Li Y, Celestino J, Dai C, Schaefer L, Sawaya RA, Fuller GN (2000) Astrocytes give rise to oligodendrogliomas and astrocytomas after gene transfer of polyoma virus middle $\mathrm{T}$ antigen in vivo. Am J Pathol 157:1031-1037. CrossRef Medline

Huang HS, Nagane M, Klingbeil CK, Lin H, Nishikawa R, Ji XD, Huang CM, Gill GN, Wiley HS, Cavenee WK (1997) The enhanced tumorigenic activity of a mutant epidermal growth factor receptor common in human cancers is mediated by threshold levels of constitutive tyrosine phosphorylation and unattenuated signaling. J Biol Chem 272:2927-2935. CrossRef Medline

Ibarrola N, Mayer-Pröschel M, Rodriguez-Peña A, Noble M (1996) Evidence for the existence of at least two timing mechanisms that contribute to oligodendrocyte generation in vitro. Dev Biol 180:1-21. CrossRef Medline

Jacques TS, Swales A, Brzozowski MJ, Henriquez NV, Linehan JM, Mirzadeh Z, O'Malley C, Naumann H, Alvarez-Buylla A, Brandner S (2010) Combinations of genetic mutations in the adult neural stem cell compartment determine brain tumor phenotypes. EMBO J 29:222-235. CrossRef Medline

Ketschek AR, Haas C, Gallo G, Fischer I (2012) The roles of neuronal and glial precursors in overcoming chondroitin sulfate proteoglycan inhibition. Exp Neurol 235:627-637. CrossRef Medline

Kitada M, Rowitch DH (2006) Transcription factor co-expression patterns indicate heterogeneity of oligodendroglial subpopulations in adult spinal cord. Glia 54:35-46. CrossRef Medline

Laks DR, Masterman-Smith M, Visnyei K, Angenieux B, Orozco NM, Foran I, Yong WH, Vinters HV, Liau LM, Lazareff JA, Mischel PS, Cloughesy TF, Horvath S, Kornblum HI (2009) Neurosphere formation is an independent predictor of clinical outcome in malignant glioma. Stem Cells 27: 980-987. CrossRef Medline

Ligon KL, Alberta JA, Kho AT, Weiss J, Kwaan MR, Nutt CL, Louis DN, Stiles CD, Rowitch DH (2004) The oligodendroglial lineage marker OLIG2 is universally expressed in diffuse gliomas. J Neuropathol Exp Neurol 63: 499-509. Medline

Lindberg N, Kastemar M, Olofsson T, Smits A, Uhrbom L (2009) Oligodendrocyte progenitor cells can act as cell of origin for experimental glioma. Oncogene 28:2266-2275. CrossRef Medline

Liu C, Sage JC, Miller MR, Verhaak RG, Hippenmeyer S, Vogel H, Foreman O, Bronson RT, Nishiyama A, Luo L, Zong H (2011) Mosaic analysis with double markers reveals tumor cell of origin in glioma. Cell 146:209221. CrossRef Medline

Liu Y, Wu Y, Lee JC, Xue H, Pevny LH, Kaprielian Z, Rao MS (2002) Oligodendrocyte and astrocyte development in rodents: an in situ and immunohistological analysis during embryonic development. Glia 40: 25-43. CrossRef Medline

Liu Y, Han SS, Wu Y, Tuohy TM, Xue H, Cai J, Back SA, Sherman LS, Fischer I, Rao MS (2004) CD44 expression identifies astrocyte-restricted precursor cells. Dev Biol 276:31-46. CrossRef Medline

Martinho O, Longatto-Filho A, Lambros MB, Martins A, Pinheiro C, Silva A, Pardal F, Amorim J, Mackay A, Milanezi F, Tamber N, Fenwick K, Ashworth A, Reis-Filho JS, Lopes JM, Reis RM (2009) Expression, mutation and copy number analysis of platelet-derived growth factor receptor $\mathrm{A}$ (PDGFRA) and its ligand PDGFA in gliomas. Br J Cancer 101:973-982. CrossRef Medline

Marumoto T, Tashiro A, Friedmann-Morvinski D, Scadeng M, Soda Y, Gage
FH, Verma IM (2009) Development of a novel mouse glioma model using lentiviral vectors. Nat Med 15:110-116. CrossRef Medline

Milosevic A, Goldman JE (2002) Progenitors in the postnatal cerebellar white matter are antigenically heterogeneous. J Comp Neurol 452:192203. CrossRef Medline

Montgomery RB, Guzman J, O'Rourke DM, Stahl WL (2000) Expression of oncogenic epidermal growth factor receptor family kinases induces paclitaxel resistance and alters beta-tubulin isotype expression. J Biol Chem 275:17358-17363. CrossRef Medline

Noble M, Fok-Seang J, Cohen J (1984) Glia are a unique substrate for the in vitro growth of central nervous system neurons. J Neurosci 4:1892-1903. Medline

Noble M, Pröschel C, Mayer-Pröschel M (2004) Getting a GR(i)P on oligodendrocyte development. Dev Biol 265:33-52. CrossRef Medline

Ogden AT, Waziri AE, Lochhead RA, Fusco D, Lopez K, Ellis JA, Kang J, Assanah M, McKhann GM, Sisti MB, McCormick PC, Canoll P, Bruce JN (2008) Identification of A2B5+CD133- tumor-initiating cells in adult human gliomas. Neurosurgery 62:505-514; discussion 514-515. CrossRef Medline

Parsons DW, Jones S, Zhang X, Lin JC, Leary RJ, Angenendt P, Mankoo P, Carter H, Siu IM, Gallia GL, Olivi A, McLendon R, Rasheed BA, Keir S, Nikolskaya T, Nikolsky Y, Busam DA, Tekleab H, Diaz LA Jr, Hartigan J, et al. (2008) An integrated genomic analysis of human glioblastoma multiforme. Science 321:1807-1812. CrossRef Medline

Perry A, Aldape KD, George DH, Burger PC (2004) Small cell astrocytoma: an aggressive variant that is clinicopathologically and genetically distinct from anaplastic oligodendroglioma. Cancer 101:2318-2326. CrossRef Medline

Persson AI, Petritsch C, Swartling FJ, Itsara M, Sim FJ, Auvergne R, Goldenberg DD, Vandenberg SR, Nguyen KN, Yakovenko S, Ayers-Ringler J, Nishiyama A, Stallcup WB, Berger MS, Bergers G, McKnight TR, Goldman SA, Weiss WA (2010) Nonstem cell origin for oligodendroglioma. Cancer Cell 18:669-682. CrossRef Medline

Power J, Mayer-Pröschel M, Smith J, Noble M (2002) Oligodendrocyte precursor cells from different brain regions express divergent properties consistent with the differing time courses of myelination in these regions. Dev Biol 245:362-375. CrossRef Medline

Raff MC, Miller RH, Noble M (1983) A glial progenitor cell that develops in vitro into an astrocyte or an oligodendrocyte depending on culture medium. Nature 303:390-396. CrossRef Medline

Rao MS, Noble M, Mayer-Pröschel M (1998) A tripotential glial precursor cell is present in the developing spinal cord. Proc Natl Acad Sci U S A 95:3996-4001. CrossRef Medline

Rebetz J, Tian D, Persson A, Widegren B, Salford LG, Englund E, Gisselsson D, Fan X (2008) Glial progenitor-like phenotype in lowgrade glioma and enhanced CD133-expression and neuronal lineage differentiation potential in high-grade glioma. PLoS ONE 3:e1936. CrossRef Medline

Singh SK, Hawkins C, Clarke ID, Squire JA, Bayani J, Hide T, Henkelman RM, Cusimano MD, Dirks PB (2004) Identification of human brain tumour initiating cells. Nature 432:396-401. CrossRef Medline

Singh A, Kong Q, Luo X, Petersen RB, Meyerson H, Singh N (2009) Prion protein (PrP) knock-out mice show altered iron metabolism: a functional role for PrP in iron uptake and transport. PLoS ONE 4:e6115. CrossRef Medline

Son MJ, Woolard K, Nam DH, Lee J, Fine HA (2009) SSEA-1 is an enrichment marker for tumor initiating cells in human glioblastoma. Cell Stem Cell 4:440-452. CrossRef Medline

Stark AM, Witzel P, Strege RJ, Hugo HH, Mehdorn HM (2003) p53, mdm2, EGFR and msh2 expression in paired initial and recurrent glioblastoma multiforme. J Neurol Neurosurg Psychiatry 74:779-783. CrossRef Medline

Steiner J, Bernstein HG, Bielau H, Berndt A, Brisch R, Mawrin C, Keilhoff G, Bogerts B (2007) Evidence for a wide extra-astrocytic distribution of S100B in human brain. BMC Neurosci 8:2. CrossRef Medline

Strathmann FG, Wang X, Mayer-Pröschel M (2007) Identification of two novel glial-restricted cell populations in the embryonic telencephalon arising from unique origins. BMC Dev Biol 7:33. CrossRef Medline

Sugawa N, Ekstrand AJ, James CD, Collins VP (1990) Identical splicing of aberrant epidermal growth factor receptor transcripts from amplified rearranged genes in human glioblastomas. Proc Natl Acad Sci U S A 87: 8602-8606. CrossRef Medline 
Swartling FJ, Savov V, Persson AI, Chen J, Hackett CS, Northcott PA, Grimmer MR, Lau J, Chesler L, Perry A, Phillips JJ, Taylor MD, Weiss WA (2012) Distinct neural stem cell populations give rise to disparate brain tumors in response to N-MYC. Cancer Cell 21:601-613. CrossRef Medline

Uhrbom L, Dai C, Celestino JC, Rosenblum MK, Fuller GN, Holland EC (2002) Ink4a-Arf loss cooperates with KRas activation in astrocytes and neural progenitors to generate glioblastomas of various morphologies depending on activated Akt. Cancer Res 62:5551-5558. Medline

Verhaak RG, Hoadley KA, Purdom E, Wang V, Qi Y, Wilkerson MD, Miller CR, Ding L, Golub T, Mesirov JP, Alexe G, Lawrence M, O'Kelly M, Tamayo P, Weir BA, Gabriel S, Winckler W, Gupta S, Jakkula L, Feiler HS, et al. (2010) Integrated genomic analysis identifies clinically relevant subtypes of glioblastoma characterized by abnormalities in PDGFRA, IDH1, EGFR, and NF1. Cancer Cell 17:98-110. CrossRef Medline

Vives V, Alonso G, Solal AC, Joubert D, Legraverend C (2003) Visualization of S100B-positive neurons and glia in the central nervous system of EGFP transgenic mice. J Comp Neurol 457:404-419. CrossRef Medline
Weiss WA, Burns MJ, Hackett C, Aldape K, Hill JR, Kuriyama H, Kuriyama N, Milshteyn N, Roberts T, Wendland MF, DePinho R, Israel MA (2003) Genetic determinants of malignancy in a mouse model for oligodendroglioma. Cancer Res 63:1589-1595. Medline

Wu Y, Liu Y, Levine EM, Rao MS (2003) Hes1 but not Hes5 regulates an astrocyte versus oligodendrocyte fate choice in glial restricted precursors. Dev Dyn 226:675-689. CrossRef Medline

Xia M, Land H (2007) Tumor suppressor p53 restricts Ras stimulation of RhoA and cancer cell motility. Nat Struct Mol Biol 14:215-223. CrossRef Medline

Yoo YM, Lee U, Kim YJ (2005) Apoptosis and nestin expression in the cortex and cultured astrocytes following 6-OHDA administration. Neurosci Lett 382:88-92. CrossRef Medline

Zeppernick F, Ahmadi R, Campos B, Dictus C, Helmke BM, Becker N, Lichter P, Unterberg A, Radlwimmer B, Herold-Mende CC (2008) Stem cell marker CD133 affects clinical outcome in glioma patients. Clin Cancer Res 14:123-129. CrossRef Medline 